\title{
Air pollution distribution in Arak city considering the effects of neighboring pollutant industries and urban traffics
}

\author{
Seyed Alireza Mostafavi ${ }^{1} \cdot$ Hamed Safikhani $^{1} \cdot$ Siavash Salehfard ${ }^{1}$
}

Received: 29 July 2020 / Accepted: 21 December 2020 / Published online: 20 January 2021

(c) Islamic Azad University 2021

\begin{abstract}
Having heavy impacts on human's life, pollution adversely influences life. In this paper, a comprehensive model of the Arak's air pollution for different pollutant chemicals $\mathrm{NO}_{x}, \mathrm{CO}$, and $\mathrm{SO}_{2}$ is developed. Here, all effective fixed and mobile sources of pollution are within $50 \mathrm{~km}$ distance of the city. The topology of ground surface and also climate patterns of different local areas were carefully considered to accurately model the distribution of pollution. Then, comparing the results with data taken from the ambient air monitoring, the model was validated. According to our findings maximum of $\mathrm{NO}_{x}$ concentration in Arak city, Iran was 7.7 times of standard value. This figure is 2.2 and 17.5 times for $\mathrm{CO}$ and $\mathrm{SO}_{2}$ pollutants. Share of industry, for spring season, is $51 \%, 86 \%$ and $100 \%$ for $\mathrm{NO}_{x}, \mathrm{CO}$, and $\mathrm{SO}_{2}$, respectively. Moreover, IRALCO itself has $31 \%$ share in total $\mathrm{NO}_{x}$ pollution, while its share for $\mathrm{CO}$ and $\mathrm{SO}_{2}$ pollution dramatically increases to $85 \%$ and $100 \%$, respectively.
\end{abstract}

Keywords Air pollution $\cdot$ Arak $\cdot$ Emission $\cdot$ Vehicle $\cdot$ Industry $\cdot \mathrm{NOx} \cdot \mathrm{CO} \cdot \mathrm{SO} 2$

\section{Introduction}

Considering the ever-increasing consumption of energy, population boom, fast-pace development, and industrialization, air pollution seems inevitable in many countries around the globe. According to WHO, it reports $91 \%$ of world's population currently live in areas with air quality higher than standard. However, the adverse trend of air quality in many areas can aggregate the health condition of the human being. As WHO reported in 2017, around 4.9 million people annually die due to being in contact with polluted air. In Iran, these data stand for 46.2 people per 100,000 of population giving a total number of 13,000 people [1].

Air pollution would be defined as the presence of certain amount of one or more pollutants, e.g., dust, particles, concentrated smoke, gas, mist, disgusting odor, and steam, in the open air. The definition also implies that characteristics of the polluted air are known continuously with the ability to prognosticate that it can endanger life of different species including human being, flora, and fauna or jeopardize individual properties or adversely interfere a decent way of life.

Seyed Alireza Mostafavi

a-mostafavi@araku.ac.ir

1 Department of Mechanical Engineering, Faculty of Engineering, Arak University, Arak, Iran
According to the report of Peel et al. being exposed to $\mathrm{NO}_{x}$ pollutants and breathing, it can cause the malfunctioning of the immunity system, increase in allergy especially in those with asthma, higher cough frequency, and decrease in long performance [2]. Kampa et al. reported that $\mathrm{CO}$ can mount on hemoglobin, and by changing its chemical properties, the capacity of oxygen transmission decreases. This descent in oxygen availability can affect the functioning of different limbs worse especially brain and heart which can result in a disturbed concentration, very slow reflexes, and confusion. Apart from lung inflammation, a systematic inflammatory variation occurs with particles and accordingly influences blood coagulation [3]. $\mathrm{SO}_{x}$ can be also oxidized and produce sulfuric acid which can cause issues such as shortage in-breath and injuries to the asthma [4].

The history of public attention to air pollution has roots in middle ages, and therefore, such an issue with its associated laws is not new at all. For instance, Edward I in 1307 banned the application of the coal in lime furnaces due to the fact that furnaces were polluting London's weather. Today, the adverse consequences of air pollution make air quality considerations inevitable as the first financial priorities in many nations. A study by Taksibi et al. compared different approaches for evaluation of environmental cost-effectiveness of different scenarios of energy policies. They focused on the Tehran metropolitan. A general policy is to stop high 
concentrations of $\mathrm{PM}_{2.5}$ and its impact on human health. Results suggested that in conventional occupations, the primary and secondary $\mathrm{PM}_{2.5}$ concentration would increase $30 \%$, on average, in the period of 2010-2030. Considering some of the scenarios seeking a reduction in pollutant concentrations can reduce the average concentration of $\mathrm{PM}_{2.5}$ up to $35 \%$ in 2020 and the number of polluted days reduces up to 20 days [5].

Pinto et al. investigated the effect of traffic data on air pollution modeling. They found that road transportation vehicles are the major contributor of the civic air pollution [6]. Mobile source emission markedly increases smallparticle pollution, $\mathrm{PM}_{2.5}$, in urban areas. In another study, the adverse health effects of $\mathrm{PM}_{2.5}$ emission from 2000 taxi cars on weekends in Peken, China were investigated. Results showed that that $\mathrm{PM}_{2.5}$ emission from transportation vehicles is higher during the week than the weekend. This finding helps to develop logical public health protocols pertained to $\mathrm{PM}_{2.5}$ emission [Tong] [7]. Tayarani et al. investigated the exposure to the small-particle pollutions caused by traffic vehicles during the day in a vast area of the urban Georgia, Atlanta, and found that $51 \%$ of the people imposed to such pollution are endangered [8].

Ghanbari Fard et al. used a neural network and a nonlinear model based on state space for modeling of the influence of the urban traffic on air pollution of Shiraz city in Iran. They investigated the behavior of the urban air pollution for a period of the $24 \mathrm{~h}$ by applying Kalman and developed Kalman filters. This modeling is based on the relation between the concentration of the pollutants and traffic load, initial pollution data, and meteorology data. Results show a great correlation between the proposed model outputs and measured data [9]. There are plenty other of studies pertaining to the effect of polluting industries in different corners of the world. Torrente et al. considered different environmental risks, e.g., gas emission by the dug wastes of Panama, and reported that solid waste as little as only $47 \mathrm{~g}$ from 1.5 million Panama City would endanger the health of the 73,600 of the people who live in the area [10]. William et al. studied the emission pattern of Ammonia/Nitrogen from a chicken farm in the eastern coast of Meryland. The coverage area of the model was $134 \mathrm{~km}$ in $230 \mathrm{~km}$ with a gridded network of $2 \mathrm{~km}$ in $2 \mathrm{~km}$. Monitoring of the ammonia concentration was performed in 23 different locations, in the eastern coast of Maryland, in two intervals within September and October 2017 for the sake of calibration. Modeling results suggested that $72.4 \%$ of ammonia emission from feeding chickens deposited back to the domain [11]. Faride Etabi et al. considered the emission behavior of the pollutants of the fourth refinery of south Pars within the $10 \mathrm{~km}^{2}$ area under investigation and showed VOC pollutants presence in adjacent cities. In further consideration of emission of the volatile organic compounds in the area, it was found that north-west wind stream $\left(315^{\circ}\right)$ in the first half of the year 2009 affected pollutant emission, whereas in the second half of that year, east-south wind stream $\left(315^{\circ}\right)$ was influential. Therefore, over the course of the year 2009, a symmetric emission pattern was observed [12].

$\mathrm{SO}_{2}$ emission of Ramin Power Plant in Ahwaz, Iran was modeled by Iman Momeni et al. They found the patterns based on the meteorology. They compared the concentration of $\mathrm{SO}_{2}$ with global standards and found that concentration of such pollutant was lower than standard limit defined by Iran's department of environment [13]. In another study, Nourpour et al. modeled the emission pattern of different pollutants, and fine particles from the stacks of Ilam cement factory. Due to the presence of the foreign particles from the western areas, it was essential to specify the exact contribution of this factory; so, samples were measured at four different locations around the factory using SKC pumps. Results suggested that the pollution of the air caused by the stack outputs is much lower than the threshold of a standard clean air [14]. Estimation of volatile organic compounds from fuel storage tanks, modeled by TANKS model, was performed by Bahman Ramavandi et al. using AERMOD model in $10 \mathrm{~km}^{2}$ vast area according to 1 -h standards in a grid distance of $200 \mathrm{~m}$. Comparing the model results with monitoring station's measured data reported by WHO, EPA, and Iran National Standard Organization showed that existed pollution in many areas is higher than the limits of the standards [15].

Mousavi et al. studied the air pollution resulted by three power plants in Mashhad, Iran using Gaussian model. Results showed that Mashhad and Shariati power plants are quite effective on Mashhad city air pollution, whereas Toos power plant seemed to be neutral. Thus, considering the superior wind stream direction over Mashhad city, it can be inferred that the location of two Mashhad and Shariati power plants is inappropriate, and in contrast, Toos power plant's location was perfectly selected [16].

Since, COVID-19 global pandemic human activities have been decreased. Studying the concentration of $\mathrm{CO}, \mathrm{PM}_{2.5}$, $\mathrm{PM}_{10}, \mathrm{SO}_{2}$, ozone, and $\mathrm{NO}_{2}$ over a month showed a reduction in the air quality index (AQI) by 44\%, 33\%, 29\%, 15\%, and $32 \%$ in north, south, east, center, and west of India, respectively [17].

A comprehensive study of ambient air quality (AAQ) in three cities of Turkey, Çanakkale area, was performed between August 2013 and 2014. AAQ measurement for bioaerosol, VOCs, $\mathrm{PMs}, \mathrm{CO}_{2}$, and $\mathrm{CO}$ was carried out for a whole year. Using AERMOD modeling system, it was found that industries were responsible for $\mathrm{NO}_{x}$ and $\mathrm{SO}_{2}$ pollutants and vehicles were dominant for $\mathrm{PM}_{10}$ and $\mathrm{CO}$ pollutants [18]. 
Overall, many studies are available focusing on air pollution in different cities to reduce the especial pollutants $[4,9,19-28]$.

Previously, the calibrated models were also established for the known pollutants in a specified city. The objective was to quantitatively obtain the sources of unknown pollutants in the future. Mahmoud Bady et al. used inverse methods to ascertain the source of pollutants in urban areas. Such a method was only used for simple cases as it possesses practical limitations [29].

According to presented studies, one of the best modeling tools with a very little error for different pollutants is AERMOD software package and the best period of study is seemingly a year with hour-to-hour data updates. Arak, the capital city of Markazi province in Iran, is a metropolitan and is a large city, in the middle of Iran, with population of 520,994 in 2017 which makes it 18th populated city of Iran. It is among the most industrialized cities of Iran quantitatively, and in terms of variety of industrial products, it is the first. As long as the presence of major industries is concerned, it is the second city of Iran. Containing major energy-related equipment manufacturer (more than $80 \%$ of total volume of such production), largest aluminum manufacturer of Iran, largest equipment manufacturer of Iran, largest train compartment, wagon and locomotive manufacturer of Middle East, largest combine manufacturer of Middle East, largest crane manufacturer of Middle East, largest fuel producer of Iran, and also large mine industries, Arak is known as the industrial capital of Iran. Arak air is among the most polluted ones in the country. Different contributors like growth in population, increase in number of vehicles, speedy industrialization, and presence of the different companies cause this city to be placed among eighth most polluted cities of Iran. In 2009 Arak was the 79th most polluted city in the globe. Air in Arak is more polluted than Tehran, capital of Iran, in terms of pollution contributors. The existence of enormous volume of pollution in this city reveals that a high percentage of pollution is concentrated over a very small area which makes it very dangerous for human life.

Traffic congestion is a problematic issue in Arak. Reasons for heavy traffic jams in Arak include ever-increasing number of vehicles, inappropriate streets, lack of allocating residential areas for widening urban roads, lack of public support for lowering traffic, weak public transportation system, and the lack of united urban management system. The number of cars in 2014 was about 148,950 in the city of Arak which means that there is a car for every four citizens. To control the traffic issue, many opinions have been already emerged like an integrated plan for Arak city traffic, building Amirkabir highway in the city, training traffic culture to the public, and traffic smart control system though performing many of these plans were given up later [30].
According to the aforementioned, considering the condition of air pollution in Arak, the precise investigation of this issue is must, so that from the air pollution modeling of Arak, the controlling policies can be obtained. The complicate of Arak air pollution modeling is the geographical location of it, because as it can be seen from Fig. 1, it is surrounded by the tall mountains. Moreover, there are many types of different industries like refinery, petrochemical, power plant, and aluminum production companies all are concentrated in this land. Finally, the presence of the worn-out cars, traffic congestion, outdated traffic space, and residential areas worsens the air pollution of this city.

In this paper, the air pollution all over the area of the city is investigated based on the released annual report of the present industries, and the details of the vehicle traffic and meteorology data were modeled and contemplated for three different pollution types of $\mathrm{NO}_{x}, \mathrm{CO}$, and $\mathrm{SO}_{x}$. The results from the proposed model were then compared with the real measured data of different measuring stations. Finally, the importance of each of the key industrial sectors as well as vehicles on each of the pollutants was analyzed and suggestions for reduction of each presented.

\section{Modeling}

Environment protection agency of the US prepared different air pollution models which are integrated in AERMOD software which is endorsed software by EPA, and therefore, it is superior to other available air pollution software packages. This software used Gaussian and dual Gaussian methods in their distribution models and it also uses different algorithms based on meteorological characteristics of the area. Here, the concentration of air pollutants can be modeled in different daily, monthly and yearly periods, and it can consider different pollution sources in the vast urban and rural areas with different geological characteristics [31].

The modeled area is shown in Fig. 1.

\section{Model input data}

Three data sets have been needed to model the air pollution as follows:

1.1.1.1.1. Data of fixed and mobile pollutant sources and the values of emission

2.2.2.2.2. Meteorology data of the area of study including low and high atmosphere data

3.3.3.3.3. Topography data including the height and depth of mountains and valleys hourly data of low atmosphere taken from meteorology data as well as high atmosphere data measured by Radiosonde and air boundary layers data, e.g., convective boundary 


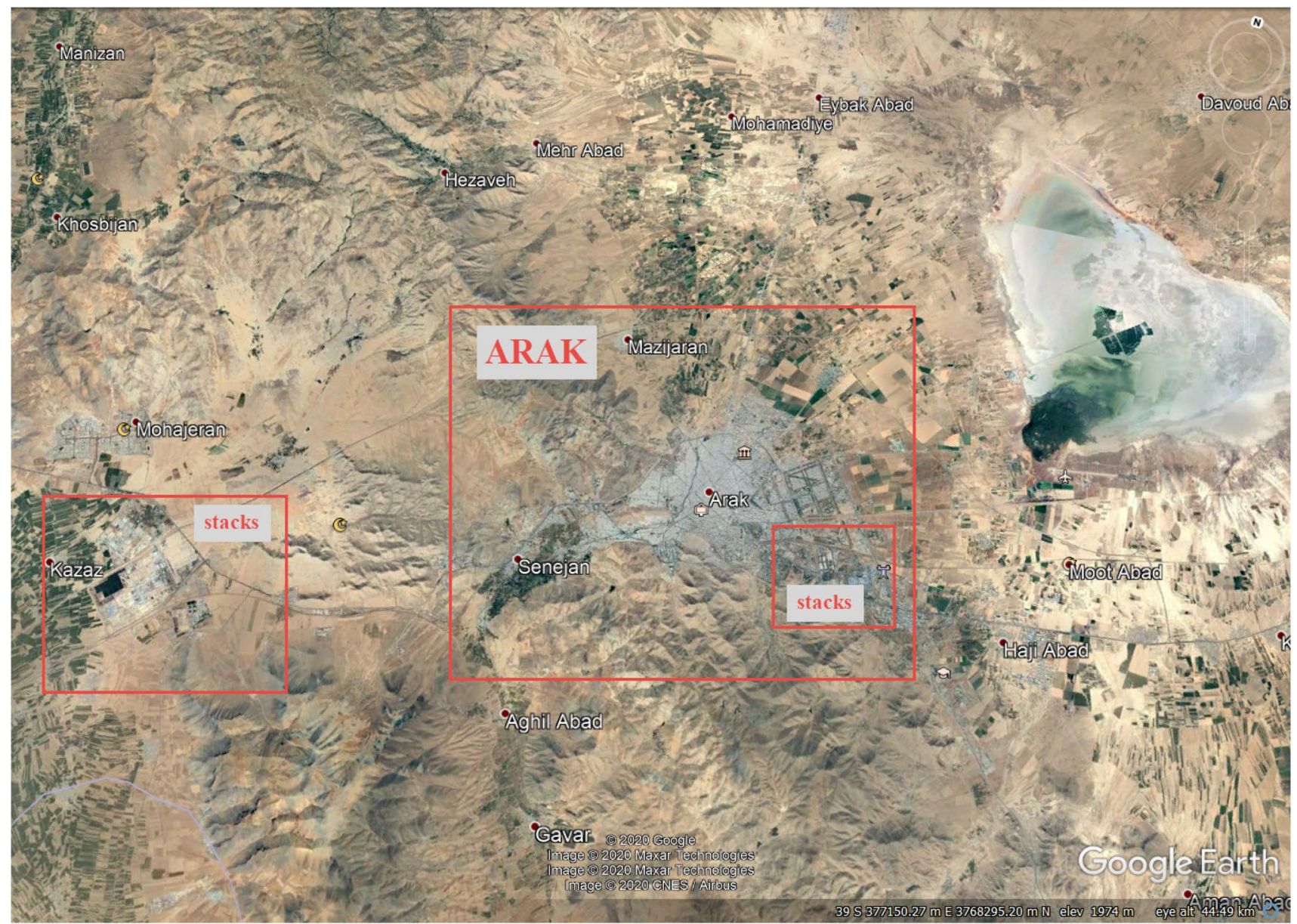

Fig. 1 The geographical location of Arak and its surrounding industries

layer, planetary boundary layer, and inversion, and model inputs, can be obtained (Table 1). This model needs minimally time data, cloudiness coefficient, temperature, humidity ratio, pressure, wind direction, and wind speed. Moreover, high atmospheric data, including pressure, temperature, humidity, and wind, are measured by specific balloons, and are included in the model. Such data are measured by the Meteorology Organization located in Arak and are applied in the present study. Acquired data are for the year 2017. The wind rose plot of Arak city is presented in Fig. 2.

Here, some considerations are important to distinguish flora and the type of the land as it is referred to municipality laws as presented in Table 2.

The data of geographical ruggedness were digitally taken using satellites and aerial images, and data of SRTM1/SRTM3 with $90 \mathrm{~m} \times 90 \mathrm{~m}$ resolution according to WGS 84 standard were applied (Fig. 3). Here, the west-south point with coordination of $35,000,0781 \mathrm{~m}$ and $37,558,343 \mathrm{~m}$ was considered as the reference where it includes of $50 \mathrm{~km} \times 30 \mathrm{~km}$ land area. Grid of receivers is selected at the elevation of $5 \mathrm{~m}$ from the ground surface. Such elevation is ordinary for the environmental measuring systems called online monitoring sets. This similarity provides a reasonable ground for comparing the results provided here with real measured data.

\section{Results}

\section{Air quality standard}

Considering the air quality standard of environment protection organization, according to Table 4 , the emission pattern of $\mathrm{NO}_{x}$ and $\mathrm{SO}_{2}$ for the period of an hour and of $\mathrm{CO}$ for $8 \mathrm{~h}$ was performed for all 365 days of the sonar year of 2017.

Air quality standard is shown in Table 3.

The distributions of fixed pollutant sources considered in the proposed model are listed in Table 4 and Fig. 4. 


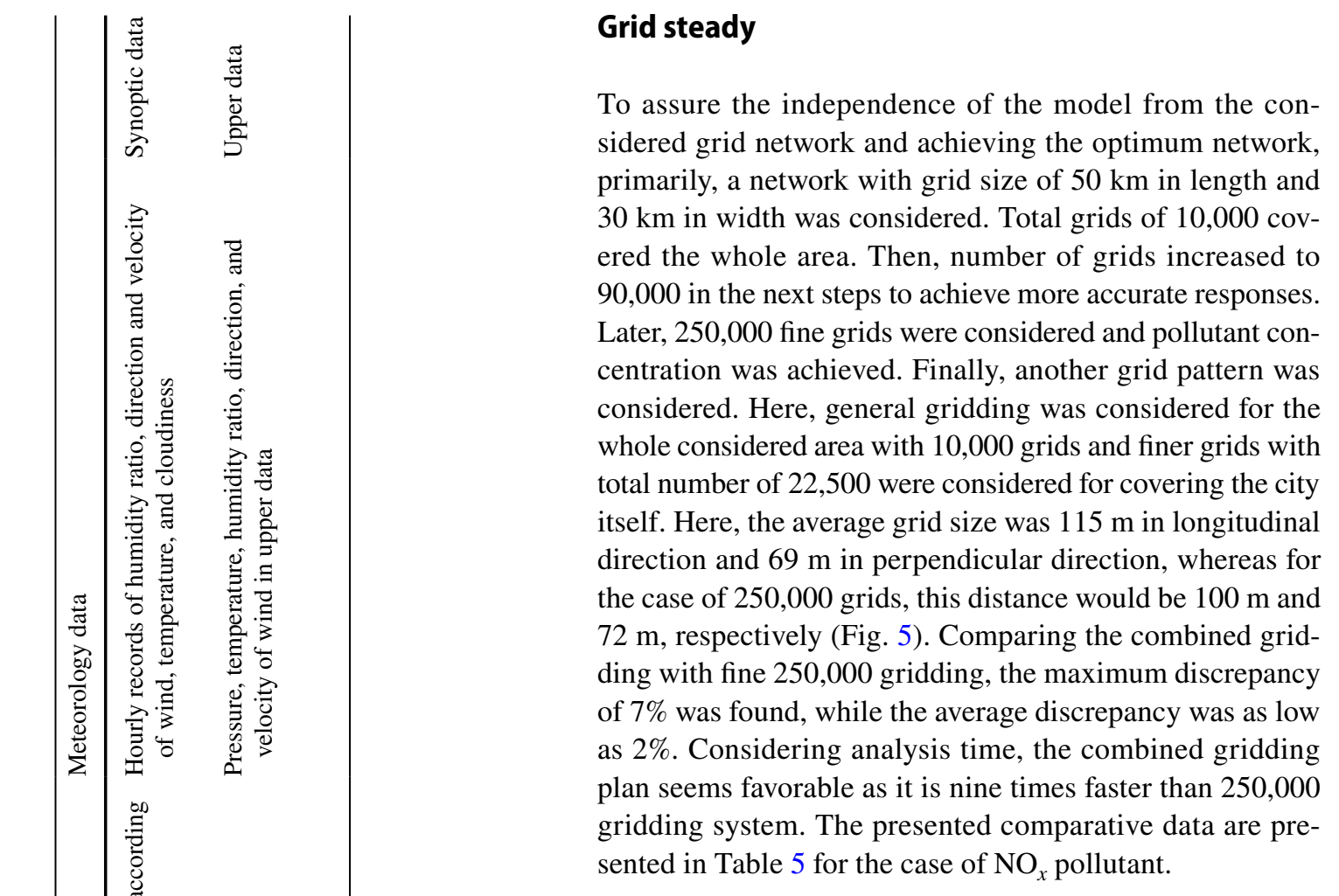

\section{Validation}

To validate the accuracy of the modeling, the resulted concentrations for different days of the year were compared with corresponding measured values of hourly monitoring stations of the environment protection organization. Table 6 shows the results as well as date considered for different ambient air monitoring stations.

\section{Distribution of pollutants in Arak metropolitan}

\section{Maximum concentration of $\mathrm{NO}_{x}$ in spring}

Figure 6 shows the distribution contour of $\mathrm{NO}_{x}$ for the spring season. According to the contours presented in Fig. 6 and data listed in Table 7, pollutant concentration for spring season was undesired for Arak and in 12 points in the city within zone $\mathrm{A}$, and in no case, the concentration was lower than the allowable limit. In most cases, the concentration of $\mathrm{NO}_{x}$ was in the range of 1000-5000 $\mu \mathrm{g} /$ $\mathrm{m}^{3}$, and for the worst case at station 3 , it was $5380 \mu \mathrm{g} / \mathrm{m}^{3}$ which is 27 times higher than the maximum allowable limit. This concentration is very detrimental to human health. The analysis of the distribution pattern reveals that in spring, much of the pollution coincides with those locations with heavier vehicle traffic. This inference is approved with considering concentrations of 5100 and $1900 \mu \mathrm{g} / \mathrm{m}^{3}$ for points $\mathrm{A}_{2}$ and $\mathrm{A}_{3}$, respectively. The pollutant $\mathrm{NO}_{x}$, in spring, is that much high that it adversely 


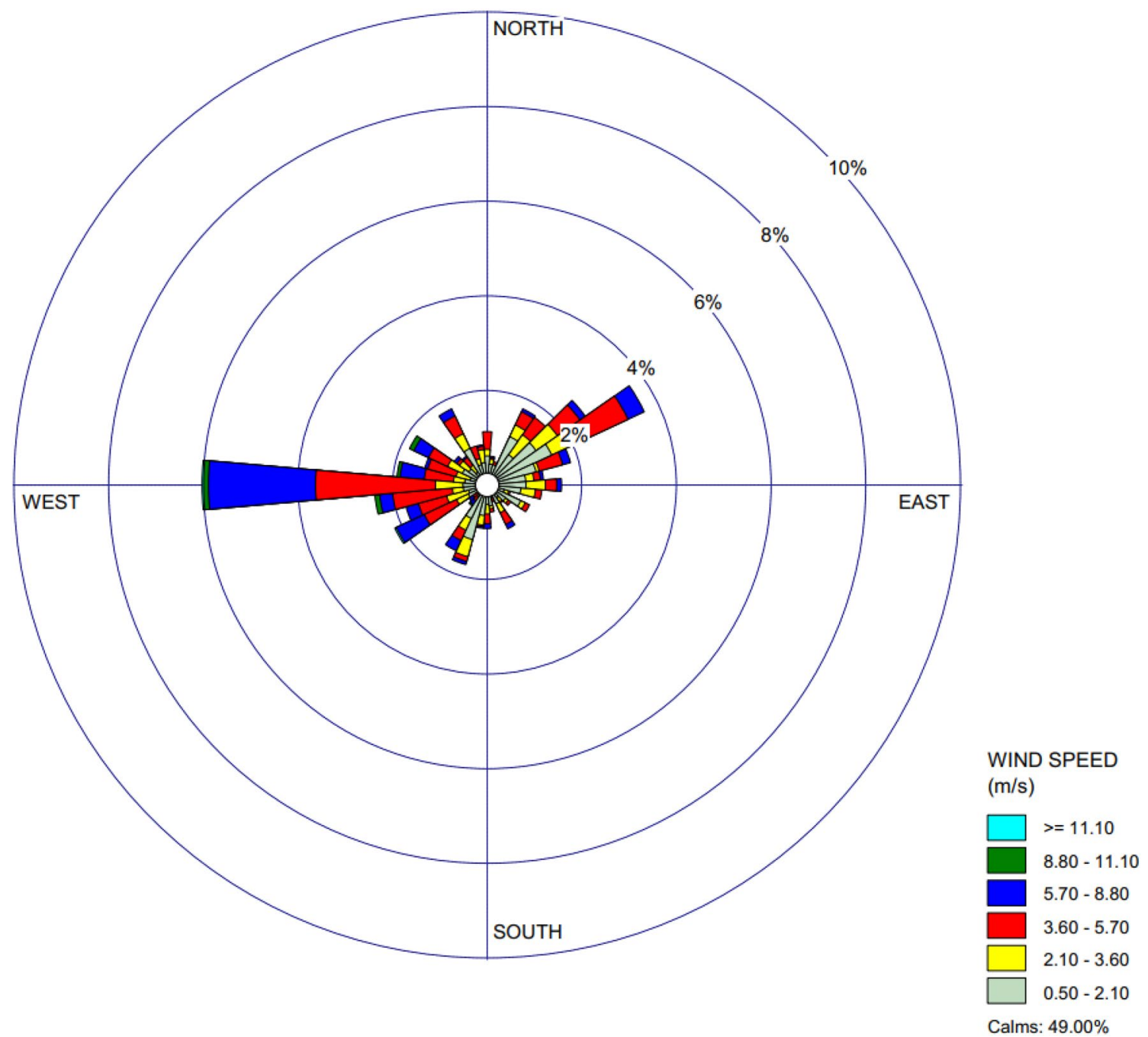

Fig. 2 Wind rose plot of Arak city in 2017

Table 2 Input meteorology data

\begin{tabular}{lllll}
\hline $\begin{array}{l}\text { Midday or } \\
\text { noon -time } \\
\begin{array}{l}\text { Albedo (nor- } \\
\text { malized) }\end{array}\end{array}$ & $\begin{array}{l}\text { Daytime } \\
\text { Bowen ratio } \\
\text { (normalized) }\end{array}$ & $\begin{array}{l}\text { Surface } \\
\text { Roughness } \\
\text { length }\end{array}$ & $\begin{array}{l}\text { Section } \\
\text { angle }\end{array}$ & $\begin{array}{l}\text { Land use } \\
\text { type }\end{array}$ \\
\hline 0.2075 & 1.65 & 1 & $0^{\circ}-180^{\circ}$ & Urban \\
0.3275 & 6 & 0.2625 & $180^{\circ}-360^{\circ}$ & Rural \\
\hline
\end{tabular}

affects the ecosystem even outside of the residential areas, e.g., Meyghan lake. As can be clear from Fig. 6 over zone $\mathrm{B}$, the presence of this pollutant is very concentrated up to $363,390 \mu \mathrm{g} / \mathrm{m}^{3}$. The white areas in the contour are attributed to the presence of the high mountains that does not let pollution expand. Comparing the contour with the superior wind stream, it can be implied that pollution moves from the west-south area to the city center. Within area B, the condition of Mohajeran city or worse than Arak city within area $\mathrm{A}$. on average the concentration of $\mathrm{NO}_{x}$ for the spring season was between 5000 and $55,000 \mu \mathrm{g} / \mathrm{m}^{3}$.

The share of vehicle traffic over $\mathrm{NO}_{x}$ in the area $\mathrm{A}_{3}$ is $85 \%$. Overall, $65 \%$ of pollutant $\mathrm{NO}_{x}$ was produced by vehicles. This shows the importance of this factor over $\mathrm{NO}_{x}$ in spring. Moreover, it can be implied that in spring, IRALCO and Arak Petrochemical Complex (ARPC) were quite effective in the presence of $\mathrm{NO}_{x}$ over Arak city.

\section{Maximum concentration of $\mathrm{NO}_{x}$ in summer}

According to the presented contour for summer in Fig. 7, it can be said the harmful concentration of $\mathrm{NO}_{x}$ still present over the city, though it is less severe than spring. In 11 points of the zone $\mathrm{A}$, the pollution is higher than the standard threshold, and on average, the condition improves about $38 \%$. In points with heavy vehicle traffic like Shohada square with $1760 \mu \mathrm{g} / \mathrm{m}^{3}$, point $\mathrm{A}_{2}$, and also point $\mathrm{A}_{3}$ 


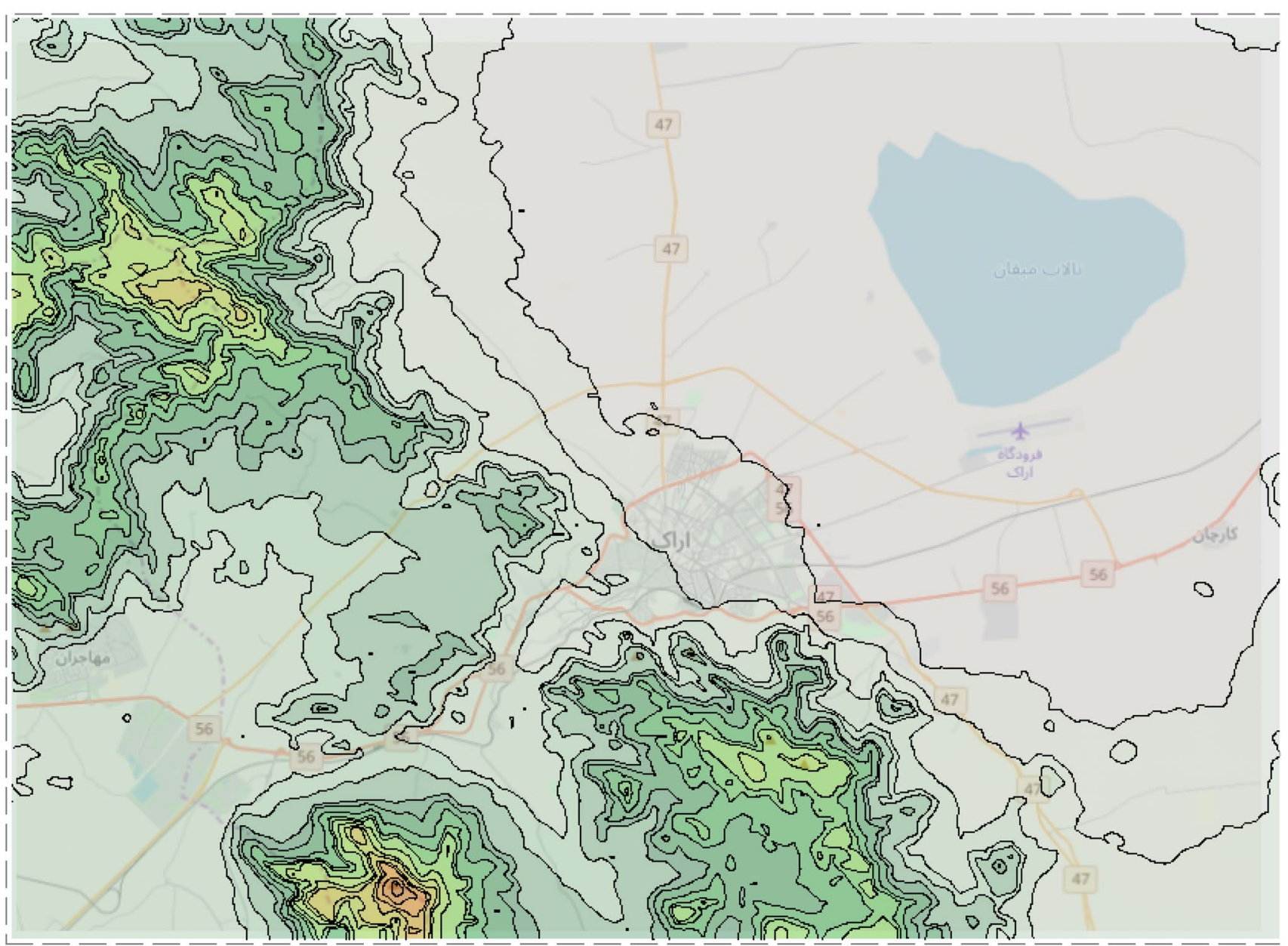

Fig. 3 Ruggedness of the land under consideration

Table 3 Air quality standard [30]

\begin{tabular}{lrll}
\hline Ppm & $\mu \mathrm{g} / \mathrm{m}^{3}$ & Period $(\mathrm{h})$ & Pollutants \\
\hline 9 & 10,000 & 8 & $\mathrm{CO}$ \\
0.075 & 196 & 1 & $\mathrm{SO}_{2}$ \\
0.1 & 200 & 1 & $\mathrm{NO}_{2}$ \\
\hline
\end{tabular}

with $5020 \mu \mathrm{g} / \mathrm{m}^{3}$, the values do not considerably change in comparison with spring as they were $1900 \mu \mathrm{g} / \mathrm{m}^{3}$ and $5100 \mu \mathrm{g} / \mathrm{m}^{3}$, respectively. Therefore, it can be concluded that much of the concentration in these areas was due to the traffic of vehicles. Another important point is that, during spring, the $\mathrm{NO}_{x}$ pollution caused by Arak Petrochemical

Table 4 The points considered

Upstream point with heavy urban traffic

Point with average urban traffic

Point with average urban traffic

Point with heavy urban traffic

Heavy urban traffic point

Heavy urban traffic point

Wind downstream point in the vicinity of industry

Point downstream of the superior wind direction near the city exit

Heavy urban traffic point

Point upstream of the superior wind-university of Arak

Point upstream of the superior wind
Station \#1

Station \#2

Station \#3

$\mathrm{A}_{1}$

$\mathrm{A}_{2}$

$\mathrm{A}_{3}$

$\mathrm{B}_{1}$

$\mathrm{B}_{2}$

$\mathrm{B}_{3}$

$\mathrm{B}_{4}$

$\mathrm{C}_{1}$ 


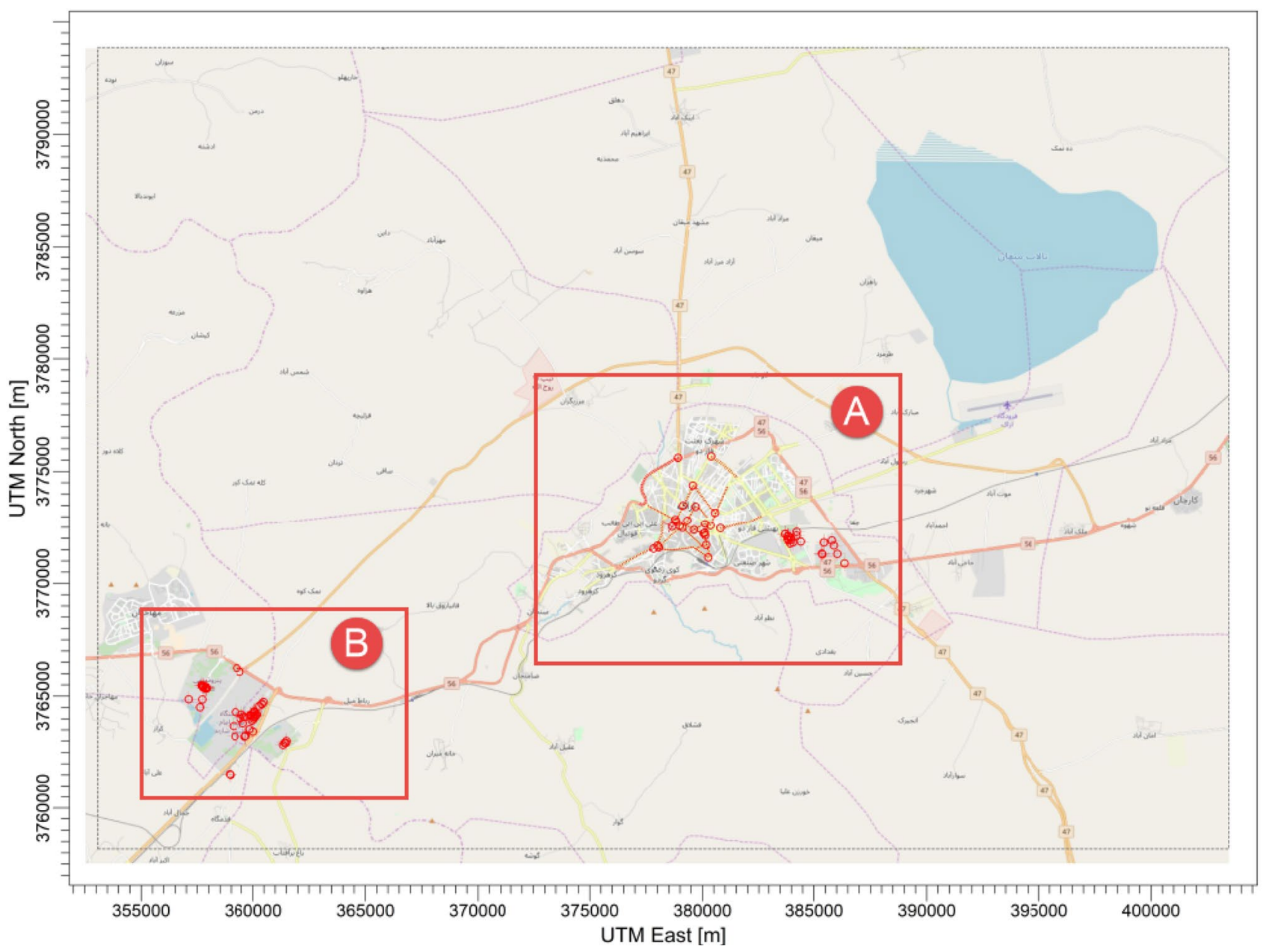

Fig. 4 Two-part receptor grid network

complex reaches the city, while in summer, this is not true anymore which proves the influence of phenomena such as air inversion and weather change from spring to summer. However, IRALCO still worsen the quality of air in terms of $\mathrm{NO}_{x}$ concentration. In zone $\mathrm{B}$, the condition is different from spring where the calm weather, as well as the presence of high mountains cause a lower distribution of the pollutants, e.g., $\mathrm{NO}_{x}$ does not reach Meyghan ecosystem. This condition of calm weather affects the concentration of zone B similarly, so that contrary to the spring, in summer condition of Mohajeran city within zone $\mathrm{B}$ is better than zone A. In Mohajeran city, the $\mathrm{NO}_{x}$ concentration in summer is in the range of $200-1000 \mu \mathrm{g} / \mathrm{m}^{3}$ which experiences a huge improvement in comparison with spring.

\section{Maximum $\mathrm{NO}_{x}$ concentration in fall}

According to the contour (Fig. 8) presented for fall, one can infer that Arak experiences a polluted condition where
11 points possess concentrations higher than the allowable limit. It should be noted, however, that the concentration at the city center, Shohada square, within point $\mathrm{A}_{2}$ decreases for about $35 \%$, in comparison with spring, and reaches to $1233 \mu \mathrm{g} / \mathrm{m}^{3}$ which is attributed to the meteorology patterns and temperature. Overall, the pollution shows 39\% decrease in comparison with spring. Moreover, the contribution of industries in zone B markedly descends as Mohajeran city has clean air in terms of $\mathrm{NO}_{x}$ pollutant. Within zone A, due to air inversion in fall, the concentration of $\mathrm{NO}_{x}$ increases at some points. For instance for station 2, the concentration becomes 1.7 times in comparison with summer. Moreover, the concentration increases in Meyghan desert. Maximum concentration occurs in zone A with $14152 \mu \mathrm{g} / \mathrm{m}^{3}$. Similar to other seasons, at points with heavy vehicle traffic, vehicles are the main contributors to the pollution. For example, at point $\mathrm{B}_{5}$, the effect of vehicles is $93 \%$ in fall. IRALCO stays a pollutant industry in fall. 


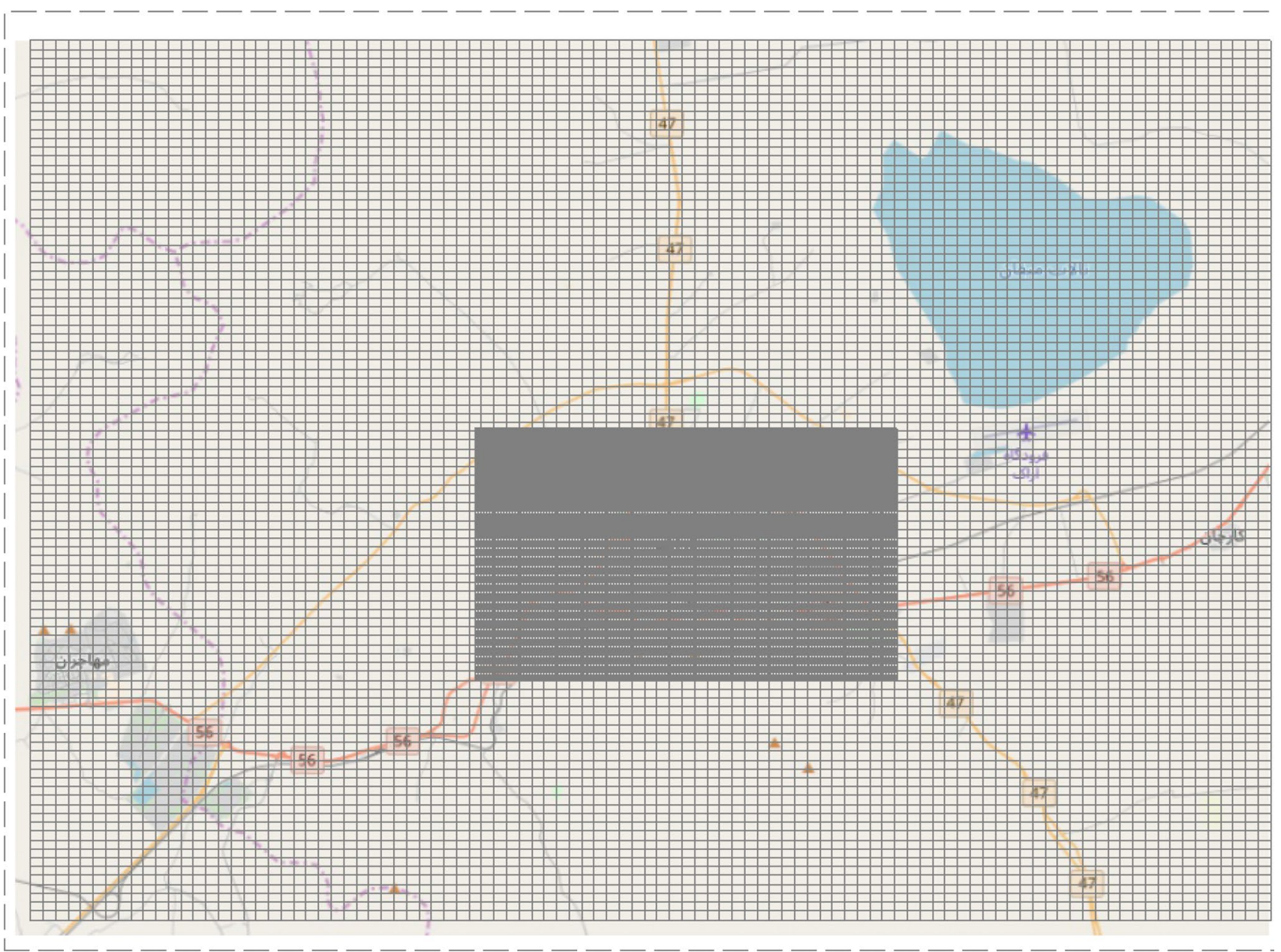

Fig. 5 Schematic of the considered area with different zones

\section{Maximum $\mathrm{NO}_{x}$ concentration in winter}

Generally, the contour of $\mathrm{NO}_{x}$ distribution reveals that $91 \%$ of considered points experience concentration higher than the allowable limit, and therefore, the condition is not desired in the city (Table 7; Fig. 9). In some points, studied relative improvements up to $83 \%$ in comparison with fall can be seen. For some points, an increase was observed. Overall, a $180 \%$ reduction in concentration of $\mathrm{NO}_{x}$ can be seen in comparison with spring. Pollution-contributor industries in winter include IRALCO, ARPC, and WagonPars, and vehicles are still major sources of $\mathrm{NO}_{x}$ emission, e.g., it holds for $83 \%$ of $\mathrm{NO}_{x}$ pollution in point $\mathrm{B}_{5}$. Moreover, zone $\mathrm{B}$, the condition of Mohajeran city almost reaches to the not-allowable condition with $178-700 \mu \mathrm{g} / \mathrm{m}^{3}$. For the case of zone A, an unfavorable condition exists in Arak due to the combined effect of heavy vehicle traffic and air inversion and meteorological patterns in winter. In some areas, this pollution penetrates to the Meyghan ecosystem.

\section{Maximum concentration of $\mathrm{SO}_{2}$ in spring}

Considering the contour presented in Fig. 10 and also data listed in Table 8, it can be seen that for spring, all areas are in harsh condition where, on average, the concentration of $\mathrm{SO}_{2}$ is 36 times higher than the allowable limit which is catastrophic for the health of citizens. Comparing different zones, it can be said that maximum concentration was for the zone A with IRALCO as the major contributor. The maximum value is $90,284 \mu \mathrm{g} / \mathrm{m}^{3}$ which is 460 times higher than $196 \mu \mathrm{g} / \mathrm{m}^{3}$ as the standard limit which occurred in zone A. This zone coincides with the crowded area of the study which can lead to a disastrous state for citizen's health. Though, other industries would emit $\mathrm{SO}_{2}$ located in zone $\mathrm{B}$, their effect would be negligible on Arak within zone A. However, they seem quite effective on the condition of Mohajeran city in zone $\mathrm{B}$ with a concentration in the range of $196-1000 \mu \mathrm{g} / \mathrm{m}^{3}$. Finally, point $B_{5}$ has the concentration 77 times higher than the standard limit. 


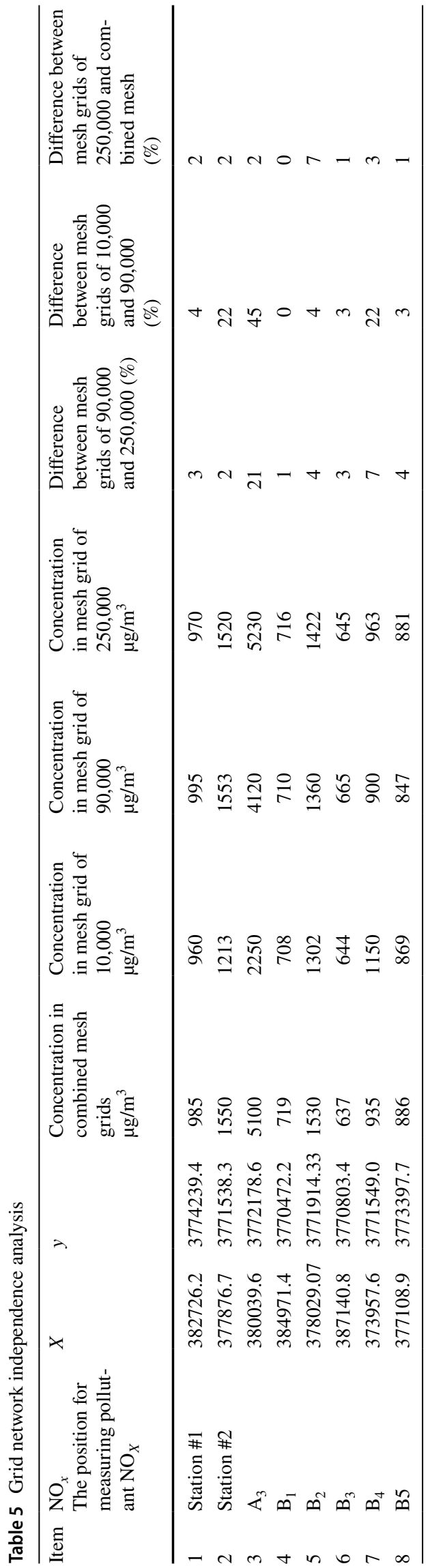

Maximum concentration of $\mathrm{SO}_{2}$ in summer

Considering the contour (Fig. 11) of $\mathrm{SO}_{2}$ concentration in summer, it can be implied that almost all studied points are in alarm condition. On average, the concentration reaches to $2656 \mu \mathrm{g} / \mathrm{m}^{3}, 13$ times higher than the standard limit. For the city center, Shohada square, within point $\mathrm{A}_{2}$, this can get up to 26 times higher-than-standard limit. Considering the contribution of vehicles, one can state that almost all pollution is caused by industries, especially IRALCO. The emission pattern of $\mathrm{SO}_{2}$ produced by IRALCO proves that the highest concentration of $35,157 \mu \mathrm{g} / \mathrm{m}^{3}$ which is 180 times higher than the standard limit lies in zone A. On the contrary, the effect of industries fades away in zone $\mathrm{B}$, where in Mohajeran city, the $\mathrm{SO}_{2}$ concentration is in the range of $196-500 \mu \mathrm{g} / \mathrm{m}^{3}$.

\section{Maximum concentration of $\mathrm{SO}_{2}$ in fall}

Considering contour (Fig. 12) and values of $\mathrm{SO}_{2}$ concentration in fall, it can be implied that all points possess a critical condition. In some points, condition is improved and some it is worsen. On average, an improvement of about $8 \%$ can be observed. Comparing the results, it can be said that the concentration in this season is lower than summer which proves the effect of climate pattern on pollution distribution. The role of vehicles is negligible. Although a portion of pollutant is produced by the Shazand refinery (IKORC), IRALCO is the pioneer in pollution producing in Arak. Maximum concentration reaches $70,619 \mu \mathrm{g} / \mathrm{m}^{3}, 360$ times higher than the standard limit located in area A. Due to a specific climate pattern and air inversion phenomenon, part of the pollution in this section is transmitted to other areas and lower is the pollution in area A. Area B is in a better condition in comparison with area $A$ and concentration in Mohajeran city is in the range of $196-700 \mu \mathrm{g} / \mathrm{m}^{3}$.

\section{Maximum concentration of $\mathrm{SO}_{2}$ in winter}

Similarly, considering contour (Fig. 13) and values of $\mathrm{SO}_{2}$ concentration in winter shows the critical condition for all areas. In $83 \%$ of the points, a promotion occurs in comparison with fall, and in other points, the situation aggregates. Generally, 37\% reduction in concentration is obvious in the urban areas. Influence of the vehicles is negligible and IRALCO is the first pollution contributor. It is noteworthy that pollution from the Shazand refinery (IKORC), in this season, adversely affects the air quality of Arak. Generally, it can be stated that winter is the best season for the minimum concentration in area $\mathrm{A}$ which can be proved from Table 8 the worst point is $B_{3}$ with $3090 \mu \mathrm{g} / \mathrm{m}^{3}$ which is due 
Table 6 Comparison of concentrations resulted from the proposed model and real measured values of different stations

\begin{tabular}{|c|c|c|c|c|c|c|}
\hline Item & Location & $x$ & $y$ & $\begin{array}{l}\text { Maximum concentration } \\
\text { resulted from model }\end{array}$ & $\begin{array}{l}\text { Maximum concentra- } \\
\text { tion measured }\end{array}$ & date \\
\hline \multirow[t]{3}{*}{$\mathrm{No}_{x}$ standard $\left(200 \mu \mathrm{g} / \mathrm{m}^{3}\right)$} & Station \#1 & 382,726 & 3774,239 & 407 & 419.55 & 21-Dec \\
\hline & Station \#2 & 377,877 & 3771,538 & 22.7 & 29.69 & $08-\mathrm{Feb}$ \\
\hline & Station \#3 & 379,815 & 3774,746 & 1840 & 1840.96 & 24-Oct \\
\hline \multirow[t]{3}{*}{ CO standard $\left(1000 \mu \mathrm{g} / \mathrm{m}^{3}\right)$} & Station \#1 & 382,726 & 3774,239 & 21,400 & - & 09-Sep \\
\hline & Station \#2 & 377,877 & 3771,538 & 6448.79 & 6458.9 & 22-Jan \\
\hline & Station \#3 & 379,815 & 3774,746 & 5386.86 & 6722.29 & 23-Jan \\
\hline \multirow[t]{3}{*}{$\mathrm{SO}_{2}$ standard $\left(196 \mu \mathrm{g} / \mathrm{m}^{3}\right)$} & Station \#1 & 382,726 & 3774,239 & 125.69 & - & 10-May \\
\hline & Station \#2 & 377,877 & 3771,538 & 56.46 & 64.97 & 10-May \\
\hline & Station \#3 & 379,815 & 3774,746 & 121.36 & - & 10-May \\
\hline
\end{tabular}

\section{Nox dispersion in Spring}

PROJECT TITLE:
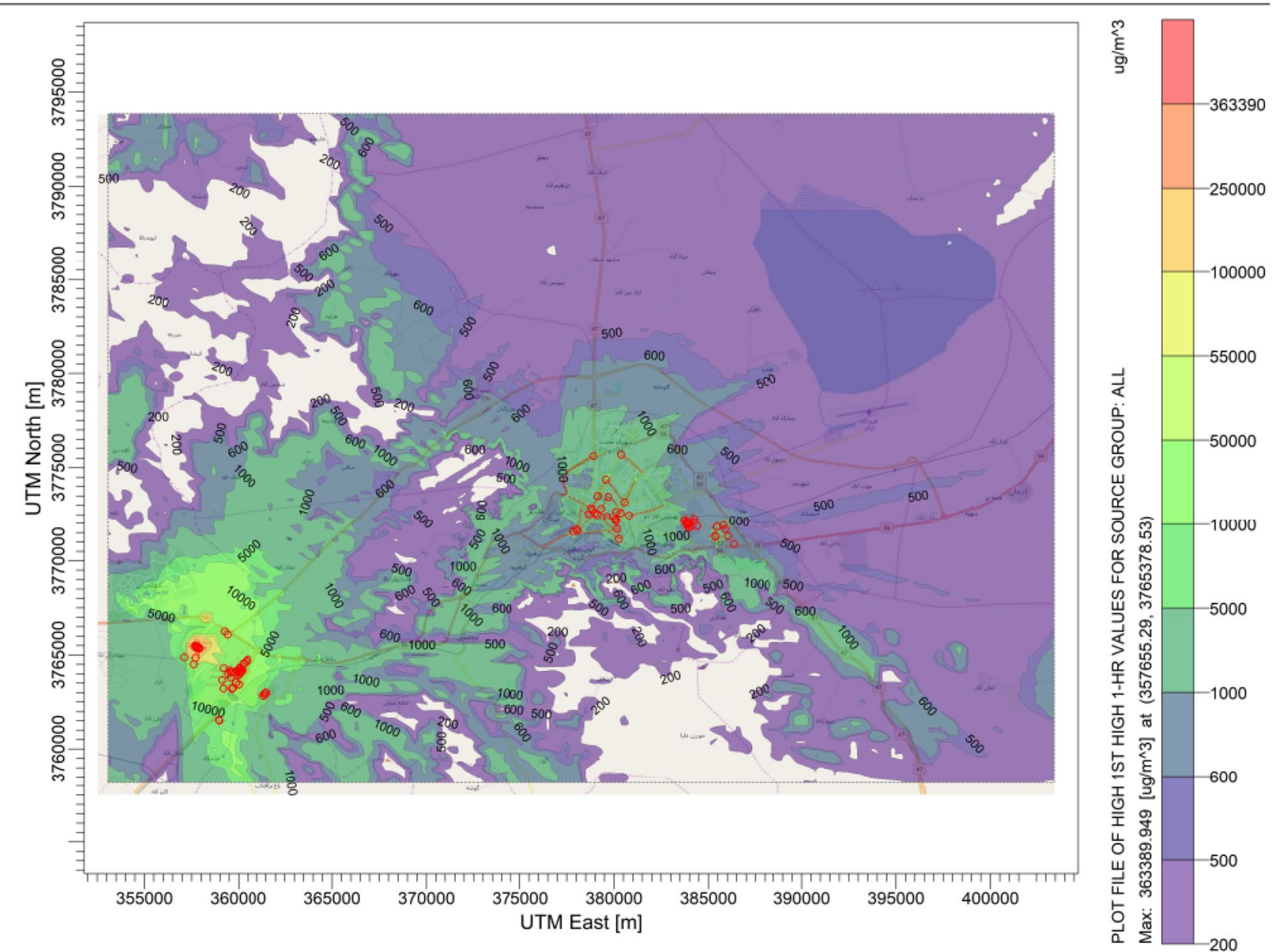

Fig. $6 \mathrm{NO}_{x}$ distribution in spring 
Table 7 Concentration of $\mathrm{NO}_{x}$ (air quality standard for $\mathrm{NO}_{x}$ is $\left.200 \mu \mathrm{g} / \mathrm{m}^{3}\right)$

\begin{tabular}{|c|c|c|c|c|c|c|c|}
\hline Item & $\begin{array}{l}\mathrm{NO}_{x} \text { measure- } \\
\text { ment location }\end{array}$ & $x$ & $y$ & $\begin{array}{l}\text { Concen- } \\
\text { tration in } \\
\text { spring } \\
\mu \mathrm{g} / \mathrm{m}^{3}\end{array}$ & $\begin{array}{l}\text { Concentra- } \\
\text { tion in sum- } \\
\text { mer } \\
\mu \mathrm{g} / \mathrm{m}^{3}\end{array}$ & $\begin{array}{l}\text { Concentra- } \\
\text { tion in fall } \\
\mu \mathrm{g} / \mathrm{m}^{3}\end{array}$ & $\begin{array}{l}\text { Concentra- } \\
\text { tion in winter } \\
\mu \mathrm{g} / \mathrm{m}^{3}\end{array}$ \\
\hline 1 & Station \#1 & $382,726.2$ & $3774,239.4$ & 985 & 392 & 1140 & 375 \\
\hline 2 & Station \#2 & $377,876.7$ & $3771,538.3$ & 1393 & 869 & 1520 & 608 \\
\hline 3 & Station \#3 & $379,814.9$ & $3774,746.4$ & 5380 & 2260 & 2870 & 2071 \\
\hline 4 & $A_{1}$ & $378,845.2$ & $3772,814.1$ & 4180 & 3091 & 3250 & 2380 \\
\hline 5 & $\mathrm{~A}_{2}$ & 379,039 & $3772,515.5$ & 1900 & 1760 & 1233 & 1413 \\
\hline 6 & $\mathrm{~A}_{3}$ & $380,039.6$ & $3772,178.6$ & 5100 & 5020 & 3360 & 5420 \\
\hline 7 & $\mathrm{~B}_{1}$ & $384,971.4$ & $3770,472.2$ & 719 & 709 & 328 & 273 \\
\hline 8 & $\mathrm{~B}_{2}$ & $378,029.07$ & $3771,914.33$ & 1870 & 1340 & 1881 & 1210 \\
\hline 9 & $\mathrm{~B}_{3}$ & $387,140.8$ & $3770,803.4$ & 637 & 605 & 297 & 207 \\
\hline 10 & $\mathrm{~B}_{4}$ & $373,957.6$ & 3771,549 & 935 & 41.9 & 52.3 & 192 \\
\hline 11 & $\mathrm{~B}_{5}$ & $377,108.9$ & $377,3397.7$ & 886 & 221 & 226 & 251 \\
\hline 12 & $\mathrm{C}_{1}$ & $36,707.9$ & $376,483.9$ & 1880 & 712 & 325 & 295 \\
\hline
\end{tabular}

\section{Nox dispersion in Summer}

PROJECT TITLE:
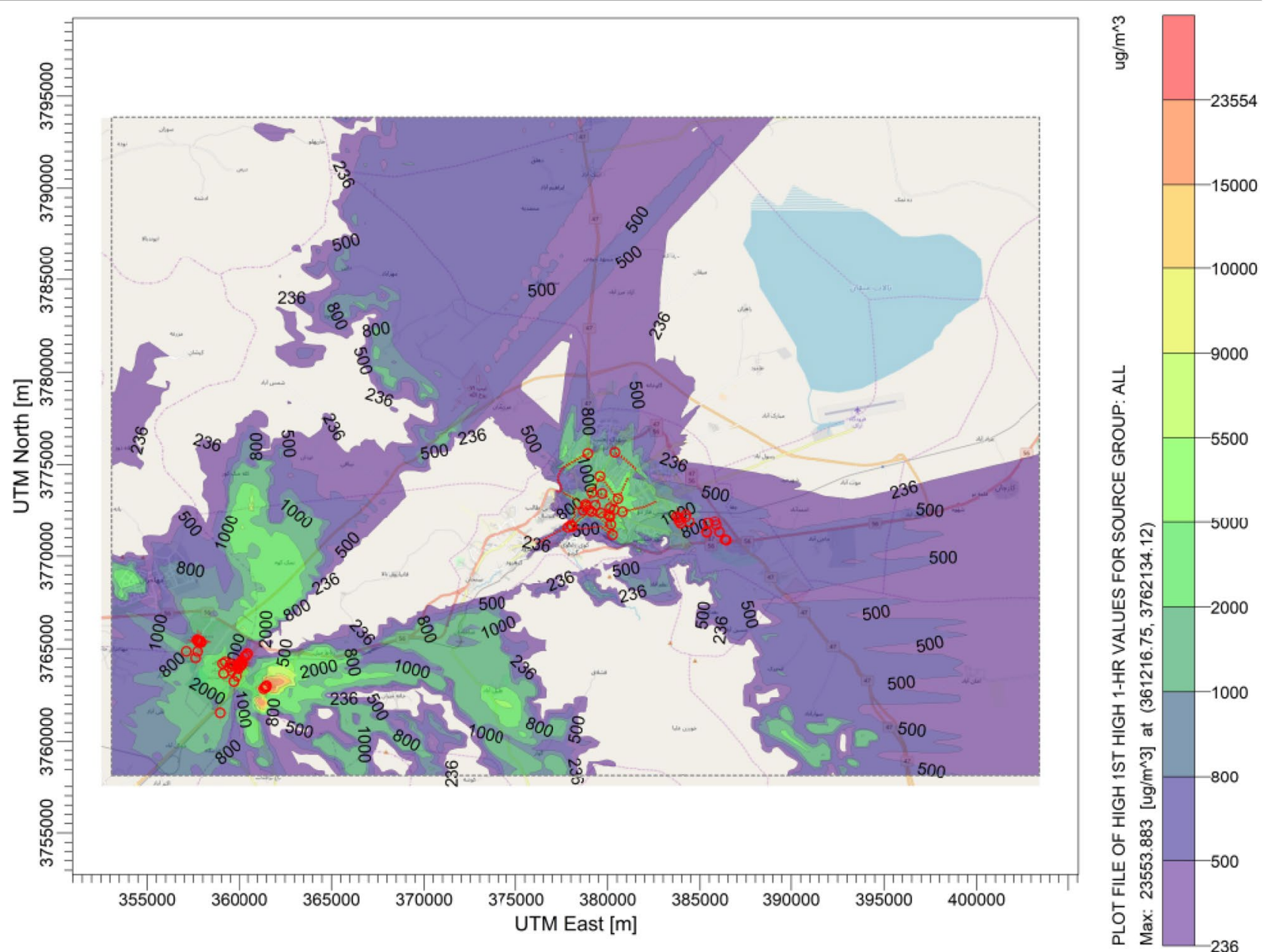

Fig. $7 \mathrm{NO}_{x}$ distribution in summer 


\section{Nox dispersion in Fall}
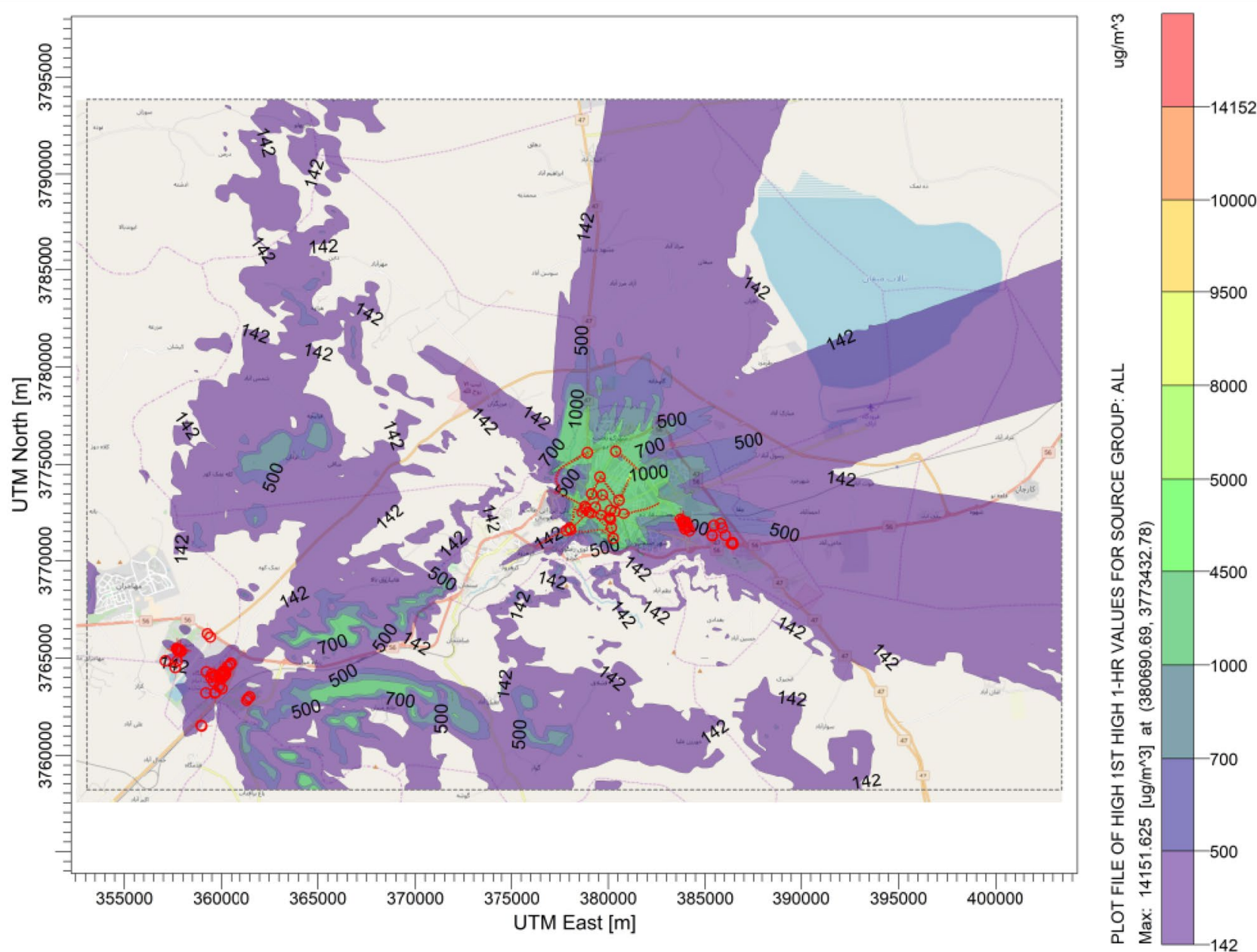

Fig. $8 \mathrm{NO}_{x}$ distribution pattern in fall

to the closeness to IRALCO and superior wind stream. The maximum concentration is $32,417 \mu \mathrm{g} / \mathrm{m}^{3}$ which is 165 times higher than the standard limit.

\section{Maximum concentration of $\mathrm{CO}$ in spring}

Considering the values of $\mathrm{CO}$ concentration in spring (Table 9; Fig. 14), it can be stated that $83 \%$ of considered points experience higher-than-standard pollution. On average, the influence of the vehicles is $21 \%$. Maximum concentration occurs in Shohada square, point $\mathrm{A}_{2}$, about $57,032 \mu \mathrm{g} / \mathrm{m}^{3}, 5.7$ times higher than the standard limit. It also can be concluded that IRALCO is the major polluter and devastates the condition in area $\mathrm{A}$, so that even
Meyghan ecosystem is affected. The highest concentration in area A equals $724,334 \mu \mathrm{g} / \mathrm{m}^{3}, 72.4$ times of the standard allowable limit, while the condition is acceptable in area B where Mohajeran city has a favorable condition.

\section{Maximum concentration of $\mathrm{CO}$ in summer}

Considering contours (Fig. 15) of CO concentration in summer, it can be inferred that for $75 \%$ of points, the concentration was higher than allowable value. In summer, on average, a total reduction of $62 \%$, in comparison with spring, can be observed for the whole area which is due to the climate pattern and change in the production of the industries. Vehicles are influential but less than IRALCO where, around its 


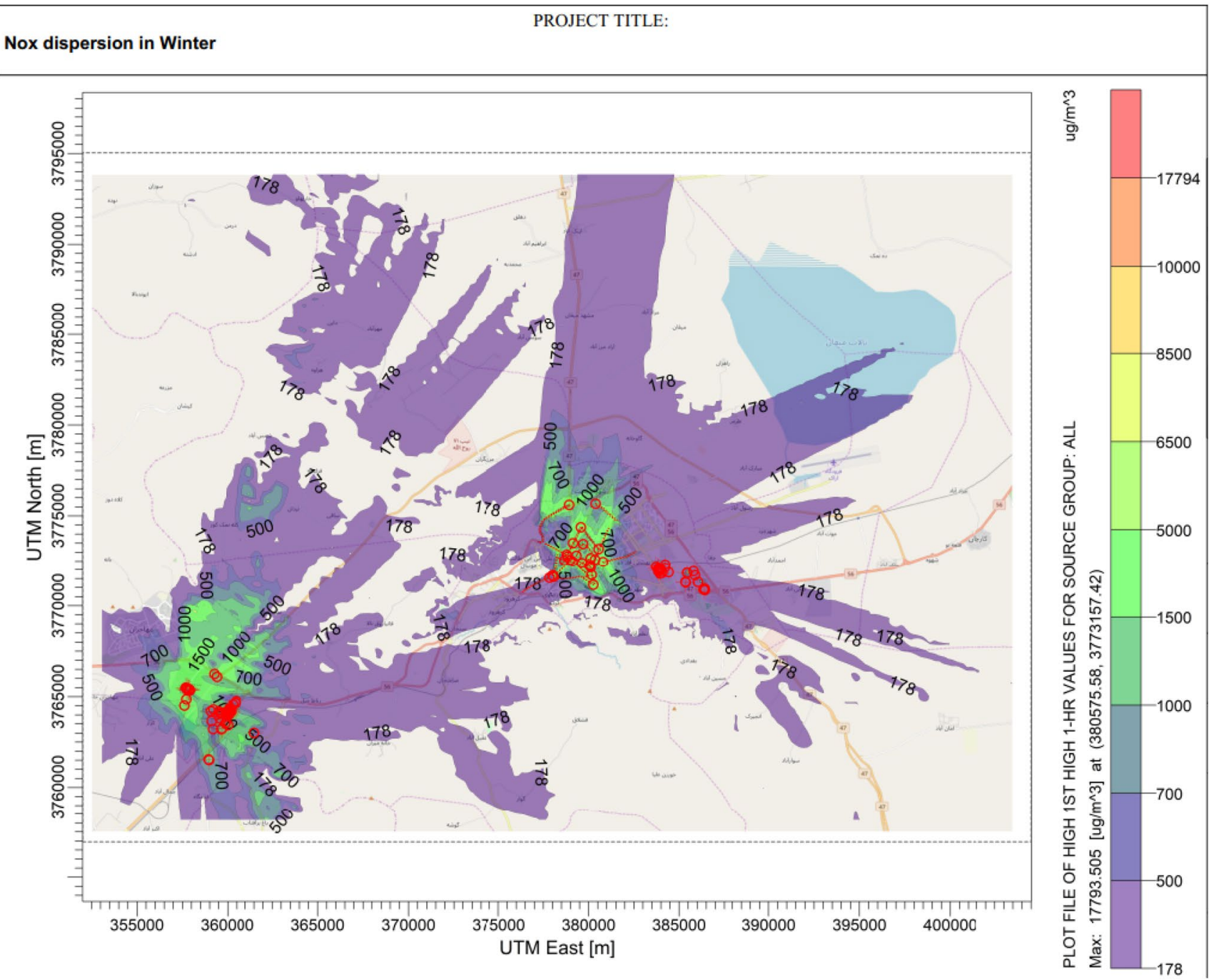

Fig. $9 \mathrm{NO}_{x}$ distribution pattern in winter

vicinity, the condition is intolerable. Though the condition for area $\mathrm{A}$ is a little better comparing with spring, maximum concentration lays in this area with $209,850 \mu \mathrm{g} / \mathrm{m}^{3}$, 21 times of allowable value. Moreover, $31,300 \mu \mathrm{g} / \mathrm{m}^{3}$ was the concentration for both $A_{1}$ and $B_{1}$ points. The source of pollution for the former is the vehicle and for the latter is IRALCO considering the superior wind stream and short distance to IRALCO. The most severe condition occurs in point $\mathrm{A}_{3}$ where it is located in lower geographical location with its high elevation surrounding which can be seen as a big pit which hinders the streams of wind and therefore higher pollution presents. Again, condition in area B is ideal and industries do not affect Mohajeran city.

\section{Maximum concentration of $\mathrm{CO}$ in fall}

Considering shown contours (Fig. 16) of CO concentration in fall, it can be observed that $75 \%$ of the considered points are under an unfavorable condition. On average, the concentration of $\mathrm{CO}$ has a $20 \%$ reduction in comparison with summer. However, the highest concentration increases by about $20 \%$ and reaches $249,325 \mu \mathrm{g} / \mathrm{m}^{3}$ which is attributed to the changes in industries' production. Again, vehicles and IRALLCO are influential. More specifically, IRALCO is responsible for the worse condition in area A. Even its pollution reaches the Meyghan ecosystem. As presented before 

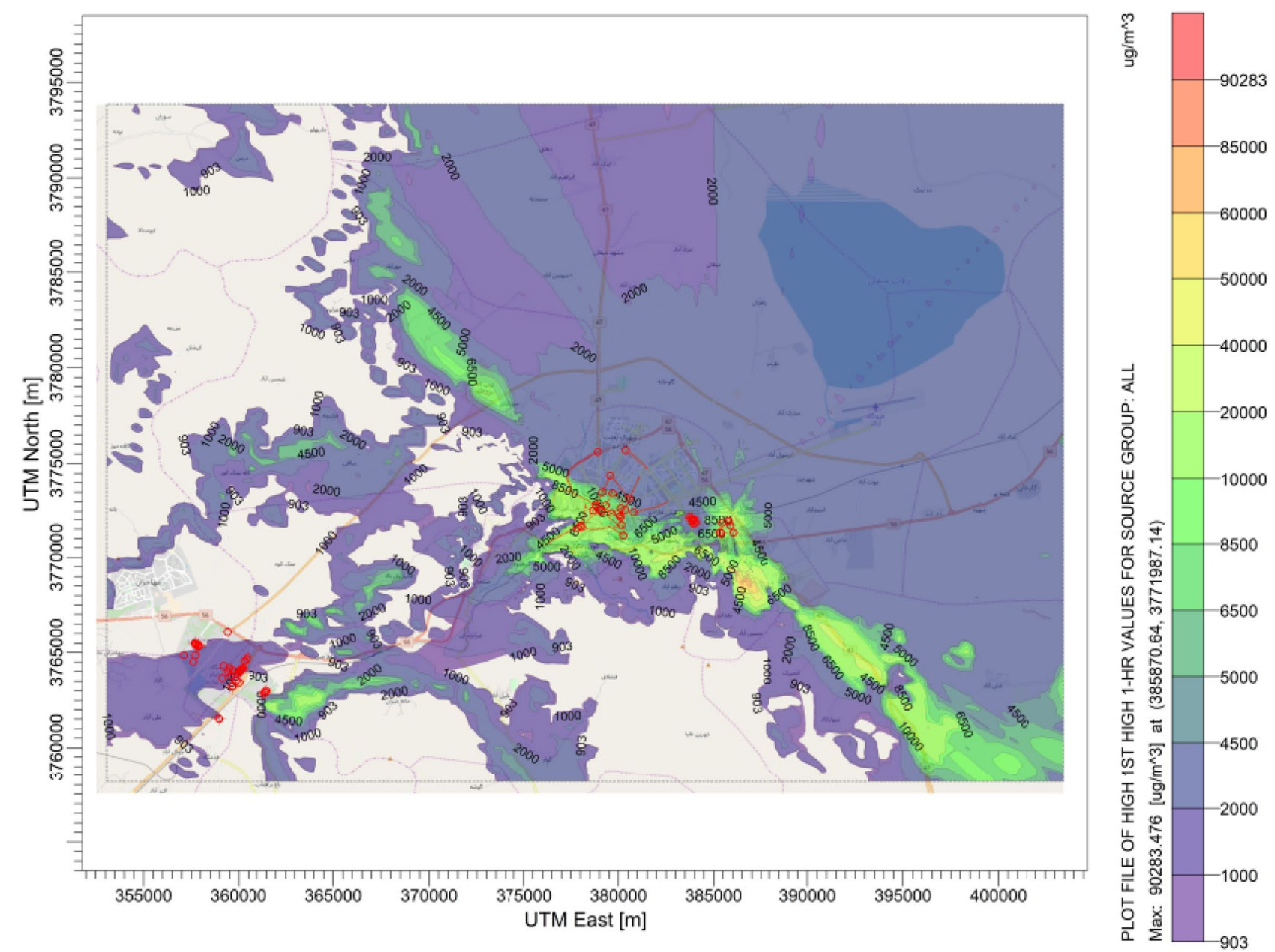

Fig. 10 Distribution pattern of $\mathrm{SO}_{2}$ in spring

Table 8 Concentration of $\mathrm{SO}_{2}$ (air quality standard for $\mathrm{SO}_{2}$ is $196 \mu \mathrm{g} / \mathrm{m}^{3}$ )

\begin{tabular}{llllclll}
\hline Item & $\begin{array}{l}\mathrm{SO}_{2} \text { measure- } \\
\text { ment location }\end{array}$ & $X$ & $y$ & $\begin{array}{l}\text { Concen- } \\
\text { tration in } \\
\text { sping } \\
\mu \mathrm{g} / \mathrm{m}^{3}\end{array}$ & $\begin{array}{l}\text { Concentra- } \\
\text { tion in sum- } \\
\text { mer } \\
\mu \mathrm{g} / \mathrm{m}^{3}\end{array}$ & $\begin{array}{l}\text { Concentra- } \\
\text { tion in fall } \\
\mu \mathrm{g} / \mathrm{m}^{3}\end{array}$ & $\begin{array}{l}\text { Concentra- } \\
\text { tion in winter } \\
\mu \mathrm{g} / \mathrm{m}^{3}\end{array}$ \\
\hline 1 & Station \#1 & $382,726.2$ & $3774,239.4$ & 3580 & 2092 & 2200 & 1720 \\
2 & Station \#2 & $377,876.7$ & $3771,538.3$ & 13,200 & 1910 & 1680 & 1180 \\
3 & Station \#3 & $379,814.9$ & $3774,746.4$ & 3310 & 1910 & 2510 & 1710 \\
4 & $\mathrm{~A}_{1}$ & $378,845.2$ & $3772,814.1$ & 10,700 & 4020 & 2650 & 1783 \\
5 & $\mathrm{~A}_{2}$ & 379,039 & $3772,515.5$ & 11,100 & 5280 & 2702 & 1774 \\
6 & $\mathrm{~A}_{3}$ & $380,039.6$ & $3772,178.6$ & 7472 & 3350 & 2690 & 1670 \\
7 & $\mathrm{~B}_{1}$ & $384,971.4$ & $3770,472.2$ & 3910 & 3104 & 3521 & 1670 \\
8 & $\mathrm{~B}_{2}$ & $378,029.07$ & $3771,914.33$ & 10,600 & 2621 & 1992 & 1170 \\
9 & $\mathrm{~B}_{3}$ & $387,140.8$ & $3770,803.4$ & 4640 & 3064 & 3510 & 3090 \\
10 & $\mathrm{~B}_{4}$ & $373,957.6$ & 3771,549 & 1170 & 804 & 387 & 680 \\
11 & $\mathrm{~B}_{5}$ & $377,108.9$ & $3773,397.7$ & 15,500 & 3300 & 2430 & 1624 \\
12 & $\mathrm{C}_{1}$ & $36,707.9$ & $376,483.9$ & 2090 & 421 & 656 & 2721 \\
\hline
\end{tabular}




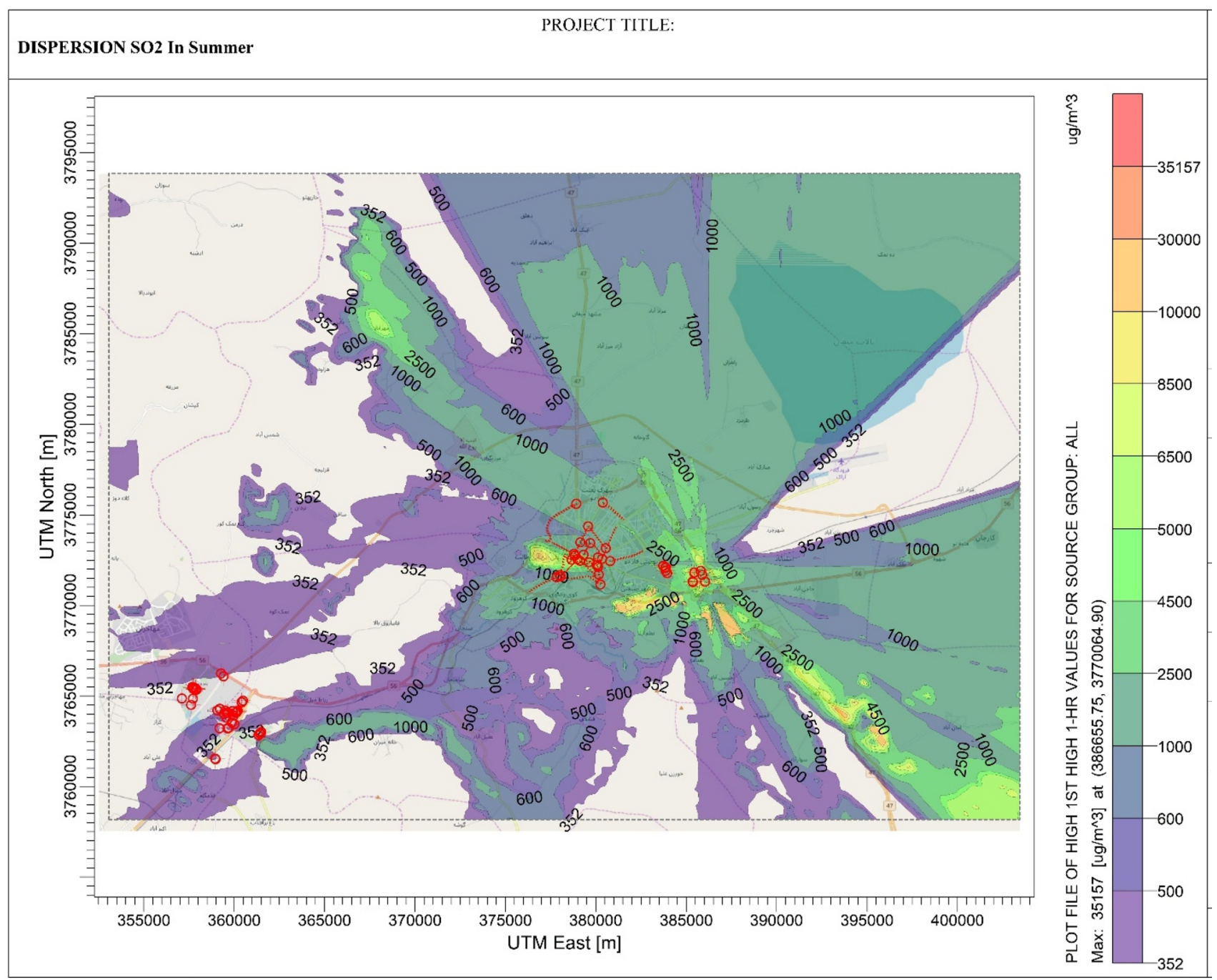

Fig. 11 Distribution pattern of $\mathrm{SO}_{2}$ in summer

in the case of summer, the most severe condition presents for point $\mathrm{A}_{3}$. Despite area $\mathrm{A}$ in the harsh condition, area $\mathrm{B}$ is clean and Mohajeran city has favorable weather.

\section{Maximum concentration of $\mathrm{CO}$ in winter}

Considering the presented contour (Fig. 17) and CO concentration (Table 9), it can be stated that $58 \%$ of points are unallowably polluted standard-wise in winter. In winter, on average, $25 \%$ reduction in concentration is observed comparing to fall. On the contrary, the highest concentration increases by about $36 \%$ and is $340,417 \mu \mathrm{g} / \mathrm{m}^{3}, 34$ times higher than the standard allowable limit which belongs to point $A_{1}$. Though vehicles are contributing to the pollution, IRALCO pollutant emission makes Arak's air condition more severe. It also adversely affects Meyghan ecosystem. Area B is safe from industrial impact and has clean weather.

\section{Determination the share of vehicles and industries in air pollution of Arak}

$\mathrm{NO}_{x}$ modeling was performed for spring and fall seasons. As can be seen in Table 10, the share of industries was a little for some points, e.g., 9\% contribution volume of total pollution in station 3. However, for points, like those in points $\mathrm{B}_{4}$ and $\mathrm{C}_{1}$, where there is very light vehicle traffic, the share of industries approaches to even $100 \%$. The average concentration in these points is $733 \mu \mathrm{g} / \mathrm{m}^{3}$ which is 3.6 times 
DISPERSION SO2 In Fall

\section{PROJECT TITLE:}
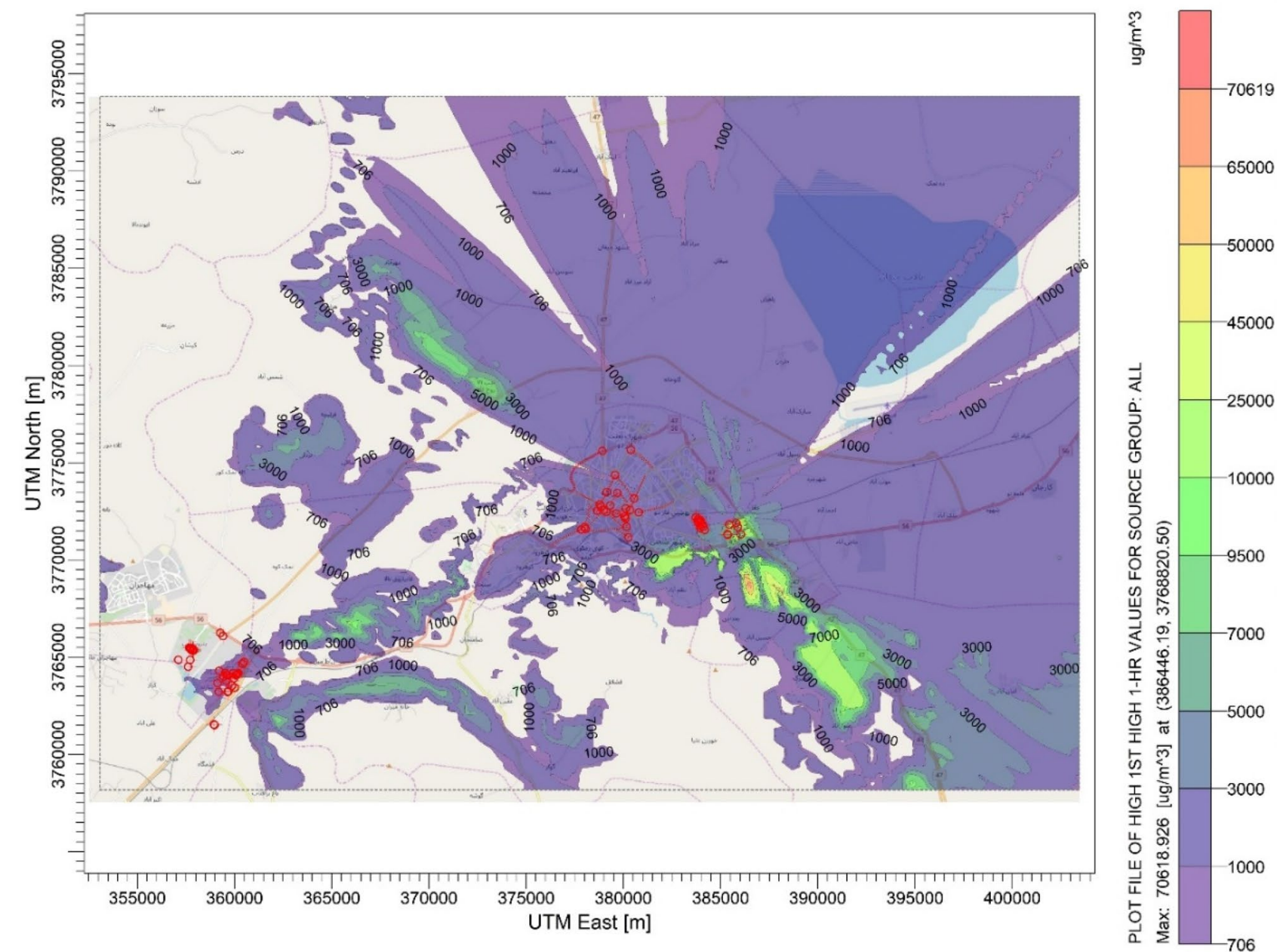

Fig. 12 Distribution pattern of $\mathrm{SO}_{2}$ in fall

higher than the standard limit. Therefore, industries and their modification must be considered the issue of air pollution is taken into account. Point $\mathrm{C}_{1}$ has the maximum concentration due to the fact it is near industries like Refinery, ARPC, and Shazand Power plant. The second point is $\mathrm{B}_{4}$ which proves a merked influence of industries on air pollution of Arak. On average, the share of the industries gets to be near $51 \%$.

In fall, since points with maximum concentration coincide with no remarkable effect of mobile sources, cars, it can be seen that the pollutant amount really decreases, and from the share of $51 \%$, here, industries contribute only to the $23 \%$ of the pollution. Similar to spring, for points $C_{1}$ and $\mathrm{B}_{4}, 100 \%$ of pollution is caused by industry. However, for points like $\mathrm{A}_{1}$ and station 3 , it can be said that mobile pollutant sources are the main contributors to the pollution and traffic control regulation can decrease the pollution in this area. The average produced concentration caused by industries is about $73 \mu \mathrm{g} / \mathrm{m}^{3}$ which contained $36 \%$ of total pollution of clean air.

Modeling of the $\mathrm{CO}$ concentration for spring excluding mobile pollutant sources is presented in Table 11. It can be observed that on the contrary to $\mathrm{NO}_{\mathrm{x}}$ where major contributors were vehicles, for the case of $\mathrm{CO}$ majority of pollution is caused by fixed sources as the share of industries reaches $86 \%$. The maximum concentration caused by industries occurs in city center, Shohada square, point $A_{2}$, 


\section{DISPERSION SO2 In Winter}

PROJECT TITLE:
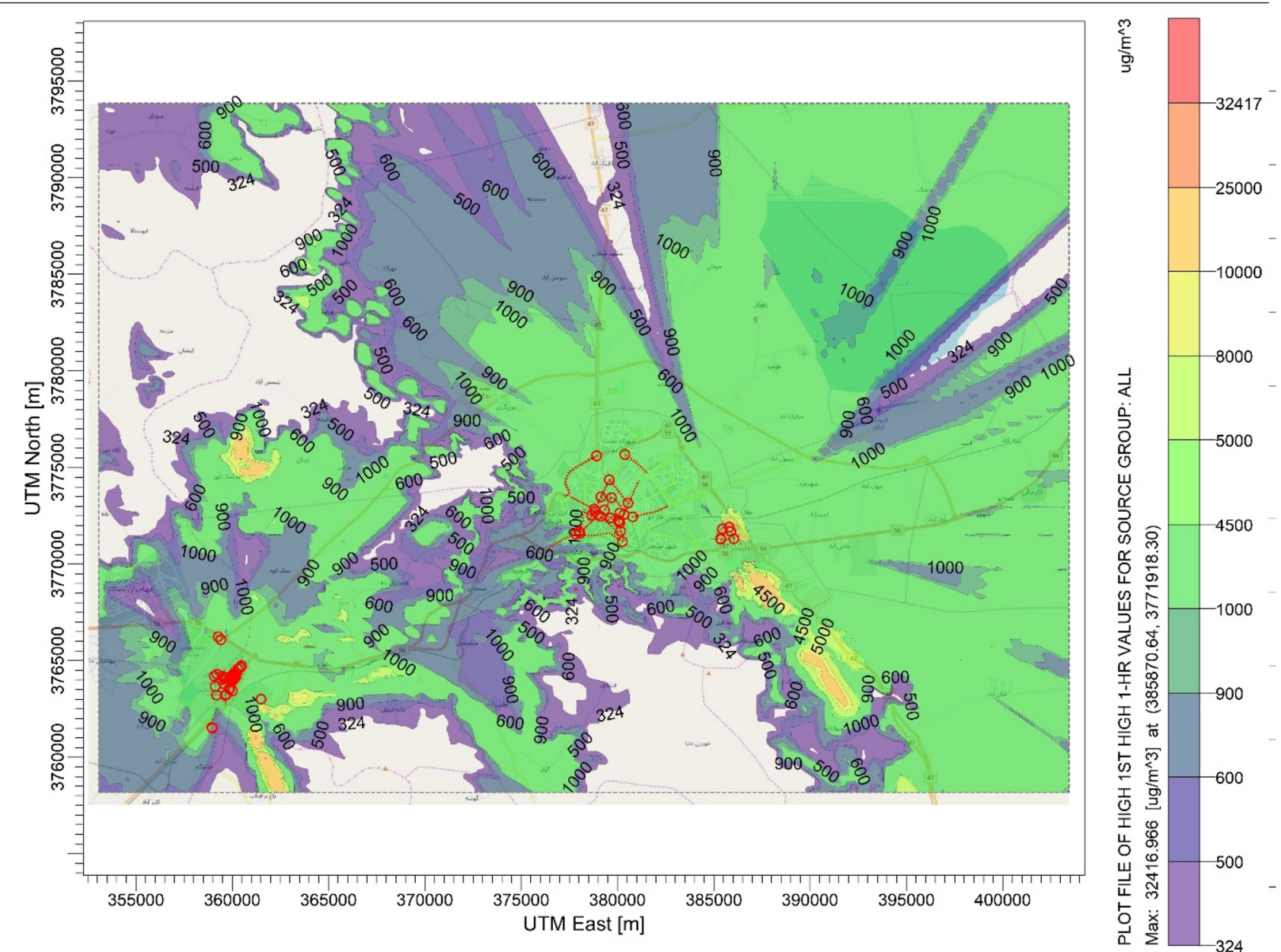

Fig. 13 Distribution pattern of $\mathrm{SO}_{2}$ in winter

which is $48,727 \mu \mathrm{g} / \mathrm{m}^{3}, 4.8$ times higher than the standard limit. Moreover, minimum concentration was at point $\mathrm{C}_{1}$ with $1970 \mu \mathrm{g} / \mathrm{m}^{3}$ below the standard limit. Considering the location of this point, it can be inferred that the contribution of ARPC and Shazand refinery (IKORC) and Shazand power plant is negligible. On the contrary, the major contributor is IRALCO. Again, if mobile sources like cars are excluded, $83 \%$ of studied points experience a higher dosage of pollutants than the standard levels. The average concentration in the area is $27,587 \mu \mathrm{g} / \mathrm{m}^{3}, 2.7$ times higher than the standard limit.

Modeling CO concentration for summer shows a slight reduction in the share of industries in comparison with spring from 86 to $78 \%$. This is due to the variation of climate and different productions of the industries. Maximum pollution belongs to point $\mathrm{B}_{1}$ equal to $31,300 \mu \mathrm{g} /$ $\mathrm{m}^{3}, 3.1$ times higher than the standard limit. Considering the concentration values and location of the measurement, it can be inferred that as locations get higher distance from IRALCO, the concentration reduces, and therefore, IRALCO is the main pollution maker of CO. Moreover, considering the concentration at $\mathrm{C}_{1}$ and $\mathrm{B}_{4}$ values, considering the superior wind stream, it is clear that industries in area $\mathrm{B}$ are ineffective. The total average of $\mathrm{CO}$ concentration over the area is $14,393 \mu \mathrm{g} / \mathrm{m}^{3}$ which is 1.4 times higher than the standard limit. 


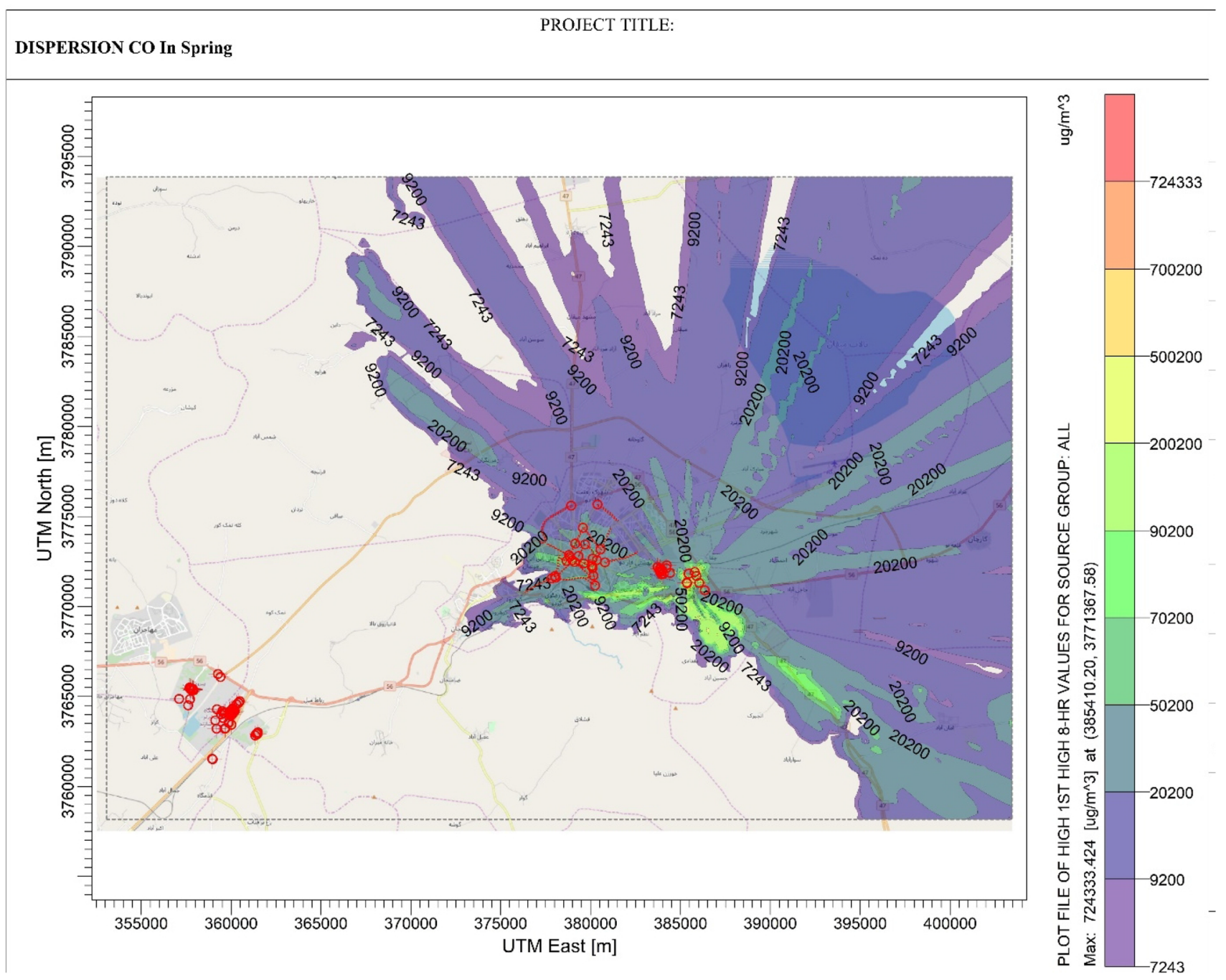

Fig. 14 Distribution pattern of CO in spring

With modeling the concentration of $\mathrm{SO}_{2}$ for both spring and summer (Table 12), a very interesting point can be highlighted. This reveals the $100 \%$ share of the industries and a negligible effect of mobile sources. As previously mentioned, the air pollution problem of Arak is mainly rooted in industries. Therefore, the first reference for modification would be industries. Considering the locations and values, it is discernable that industries are very influential over two areas A and B.

Bearing in mind the major contribution of IRALCO in all studied pollutants, it was decided to model the effect of only IRALCO on ARAK air pollution. It would be also interesting to see what would happen if the pollution produced by IRALCO becomes half of its current value? In the following, this notion is more investigated.

For the case of $\mathrm{NO}_{x}$ modeling was performed only for spring and fall, because the pollution was maximized in these two seasons. Table 13 shows the concentration for 12 points of the city.

As was expected, IRALCO possesses a high percentage share for the $\mathrm{NO}_{x}$, on average $31 \%$, which would cause a lot of health problems for citizens. More intriguing is the fact that even with the assumption of no mobile pollutant source, the crowded area of the city, e.g., Shohada square, at point $\mathrm{A}_{2}$, is heavily polluted with about $647 \mu \mathrm{g} /$ $\mathrm{m}^{3}$ which is almost three times higher-than-standard limit and contains almost $34 \%$ of the total concentration. 
DISPERSION CO In Summer

PROJECT TITLE:
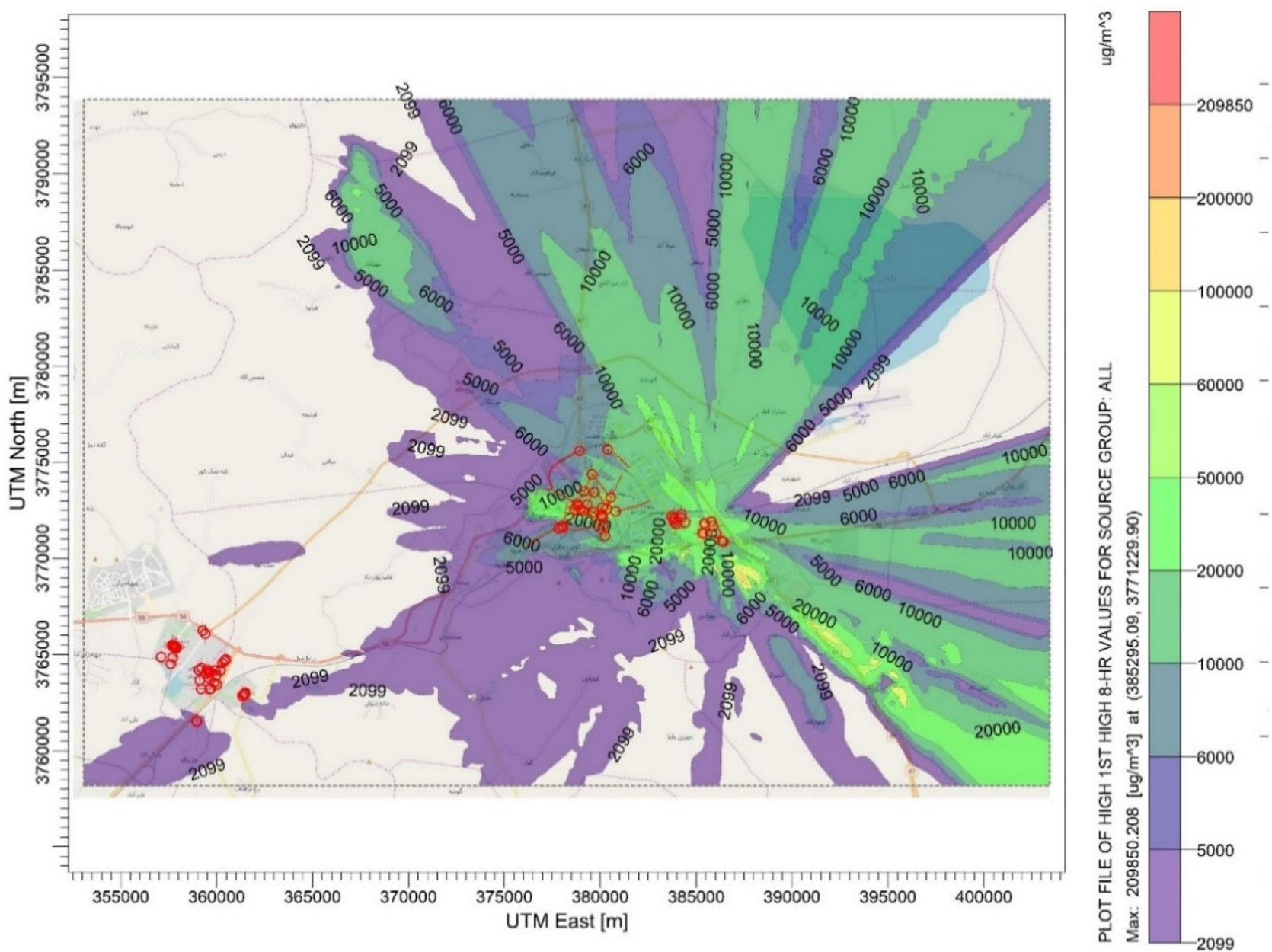

Fig. 15 Distribution pattern of $\mathrm{CO}$ in summer

In the fall, the effect of IRALCO on Arak remarkably reduces and it becomes $8 \%$ of the total concentration. This reduction is attributed to the fact that some stacks were out of service and they had zero discharge. In this season, IRALCO does not have that adverse influence on Arak air pollution and its performance is assessed acceptable.

Now, analysis with half of the IRALCO's pollution is discussed. For spring, seven points out of total 12 points again have higher pollutant concentrations which not desired. On average, it produces on average $228 \mu \mathrm{g} / \mathrm{m}^{3}$ over the area which is still higher than the standard limit.

For the fall season, reducing the pollution in half would provide cleaner air for citizens, though even with the current rated pollution, there was no urgent condition in terms of $\mathrm{NO}_{x}$ concentration.

Modeling of CO was performed for only spring and fall, because they possess the highest dosage of this pollutant. Table 14 lists the results for 12 measuring points. 


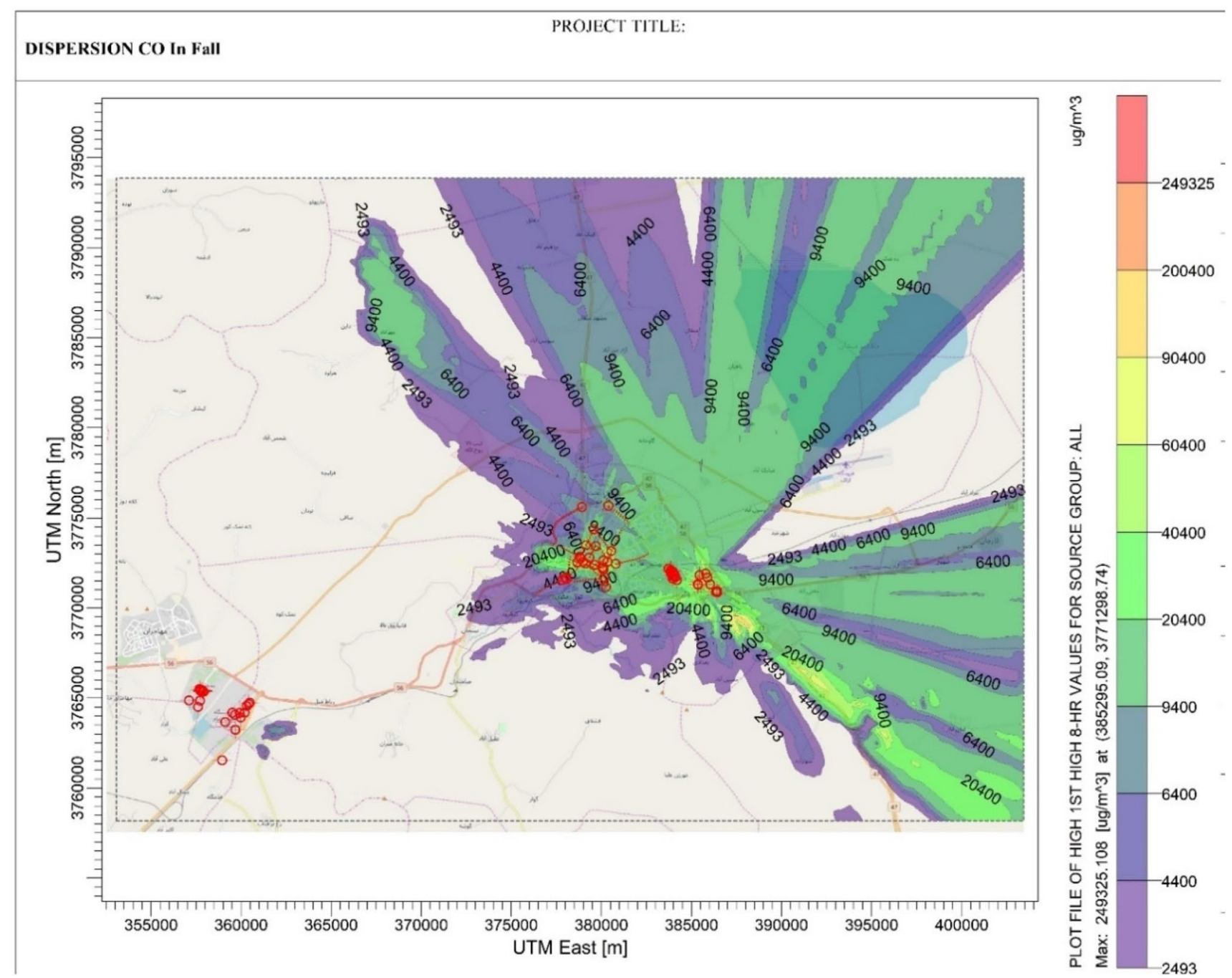

Fig. 16 Distribution pattern of $\mathrm{CO}$ in fall

Comparing the concentration values, it can be inferred that the major reason of the pollution was IRALCO Company. On average, the percentage of contribution of IRALCO over the whole area of study was about $85 \%$ which shows the real impact of this company on pollution in this season. The maximum pollutant produced is at Shohada square at point $\mathrm{A}_{2}$ about $48,719 \mu \mathrm{g} / \mathrm{m}^{3}, 4.8$ times higher than the allowable level. $83 \%$ of studied points experience higher-than-standard levels of pollution where the only reason is IRALCO. The average of the points has the concentration of $27,419 \mu \mathrm{g} / \mathrm{m}^{3}$, 2.7 times higher than the standard limit.

Modeling $\mathrm{CO}$ in summer again confirms the major contribution of IRALCO with $77 \%$ on average. The highest concentration occurs at point $B_{1}$ with $31,300 \mu \mathrm{g} / \mathrm{m}^{3}, 3.1$ times higher than allowable threshold. Overall, $66 \%$ of the studied points have a concentration higher than the permitted value.

With making the emission volume of IRALCO half, in spring, $58 \%$ of the points still experience, on average, 


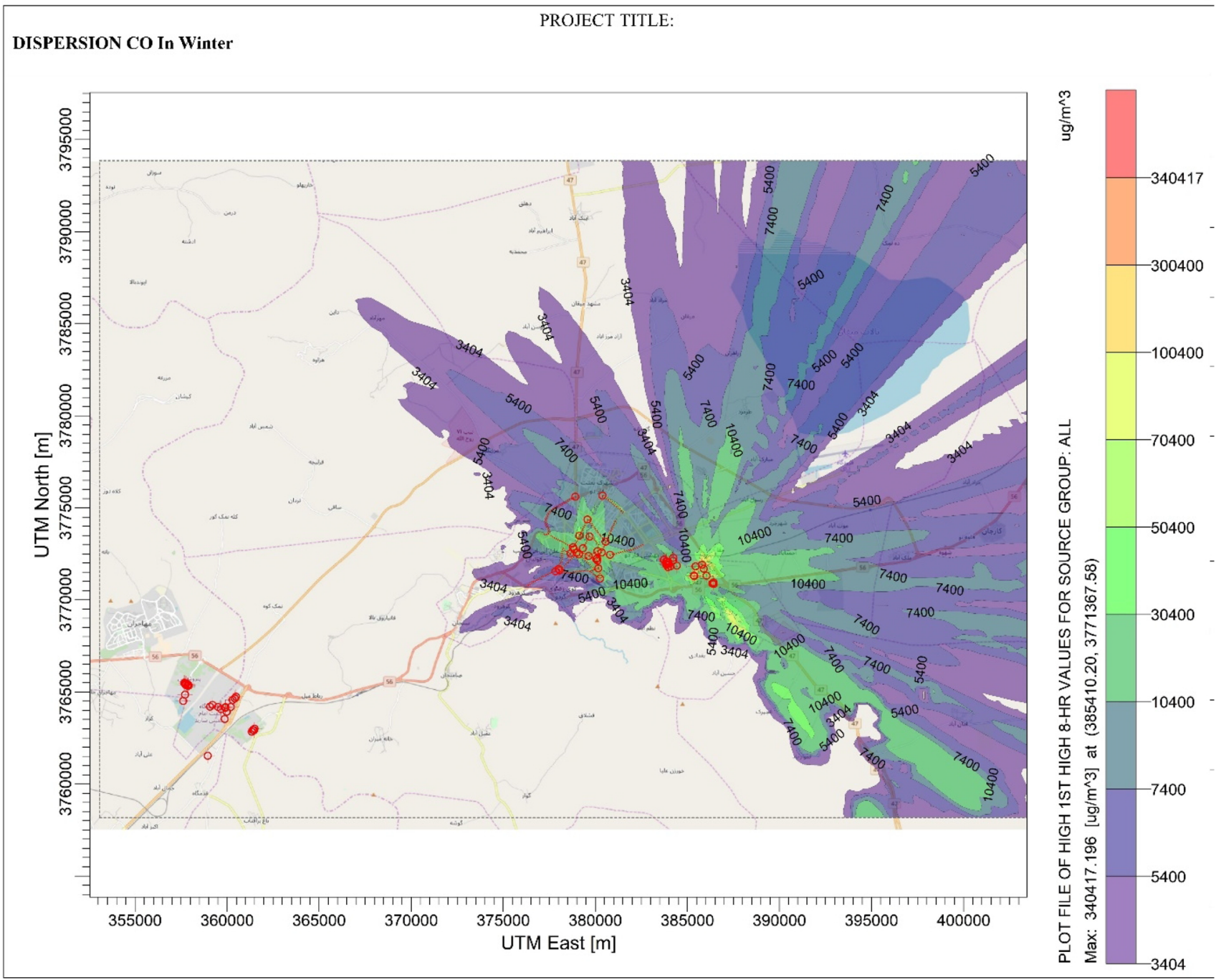

Fig. 17 Distribution pattern of $\mathrm{CO}$ in winter

Table 9 Concentration of $\mathrm{CO}$ (air quality standard for $\mathrm{CO}$ is $10,000 \mu \mathrm{g} / \mathrm{m}^{3}$ )

\begin{tabular}{lllllrrr}
\hline Item & $\begin{array}{l}\text { CO measure- } \\
\text { ment location }\end{array}$ & $y$ & $\begin{array}{l}\text { Concen- } \\
\text { tration in } \\
\text { spring } \\
\mu \mathrm{g} / \mathrm{m}^{3}\end{array}$ & $\begin{array}{l}\text { Concentra- } \\
\text { tion in sum- } \\
\text { mer } \\
\mu \mathrm{g} / \mathrm{m}^{3}\end{array}$ & $\begin{array}{l}\text { Concentra- } \\
\text { tion in fall } \\
\mu \mathrm{g} / \mathrm{m}^{3}\end{array}$ & $\begin{array}{l}\text { Concentra- } \\
\text { tion in winter } \\
\mu \mathrm{g} / \mathrm{m}^{3}\end{array}$ \\
\hline 1 & Station \#1 & $382,726.2$ & $3774,239.4$ & 19,200 & 18,200 & 13,500 & 9673 \\
2 & Station \#2 & $377,876.7$ & $3771,538.3$ & 46,121 & 8740 & 6641 & 7261 \\
3 & Station \#3 & $379,814.9$ & $3774,746.4$ & 39,200 & 18,719 & 17,948 & 14,700 \\
4 & $\mathrm{~A}_{1}$ & $378,845.2$ & $3772,814.1$ & 49,646 & 31,300 & 27,248 & 38,316 \\
5 & $\mathrm{~A}_{2}$ & 379,039 & $3772,515.5$ & 57,032 & 26,500 & 21,100 & 33,308 \\
6 & $\mathrm{~A}_{3}$ & $380,039.6$ & $3772,178.6$ & 78,027 & 49,800 & 49,800 & 15,347 \\
7 & $\mathrm{~B}_{1}$ & $384,971.4$ & $3770,472.2$ & 23,137 & 31,300 & 24,700 & 15,300 \\
8 & $\mathrm{~B}_{2}$ & $378,029.07$ & $3771,914.33$ & 47,100 & 17,400 & 16,548 & 7701 \\
9 & $\mathrm{~B}_{3}$ & $387,140.8$ & $3770,803.4$ & 18,448 & 22,822 & 22,400 & 13,323 \\
10 & $\mathrm{~B}_{4}$ & $37,3957.6$ & 3771,549 & 4640 & 3970 & 2820 & 3940 \\
11 & $\mathrm{~B}_{5}$ & $37,7108.9$ & $3773,397.7$ & 36,849 & 28,414 & 11,036 & 11,800 \\
12 & $\mathrm{C}_{1}$ & $36,707.9$ & $376,483.9$ & 1971 & 2083 & 1512 & 1004 \\
\hline
\end{tabular}


Table $10 \mathrm{NO}_{x}$ concentration caused only by industries

\begin{tabular}{|c|c|c|c|c|c|c|c|c|c|}
\hline Item & $\begin{array}{l}\mathrm{NO}_{x} \text { Measure- } \\
\text { ment location } \\
\text { only for } \\
\text { industries }\end{array}$ & $X$ & $Y$ & $\begin{array}{l}\text { Concen- } \\
\text { tration in } \\
\text { spring } \\
\mu \mathrm{g} / \mathrm{m}^{3}\end{array}$ & $\begin{array}{l}\text { Industries- } \\
\text { caused } \\
\text { concentration } \\
\text { in spring } \\
\mu \mathrm{g} / \mathrm{m}^{3}\end{array}$ & $\begin{array}{l}\text { Share of indus- } \\
\text { tries from total } \\
\text { concentration } \\
(\%)\end{array}$ & $\begin{array}{l}\text { Concen- } \\
\text { tration in } \\
\text { fall } \\
\mu \mathrm{g} / \mathrm{m}^{3}\end{array}$ & $\begin{array}{l}\text { Industries- } \\
\text { caused } \\
\text { concentration } \\
\text { in fall } \\
\mu \mathrm{g} / \mathrm{m}^{3}\end{array}$ & $\begin{array}{l}\text { Share of indus- } \\
\text { tries from total } \\
\text { concentration } \\
(\%)\end{array}$ \\
\hline 1 & Station \#1 & $382,726.2$ & $3774,239.4$ & 985 & 418 & 42 & 1140 & 45.1 & 4 \\
\hline 2 & Station \#2 & $377,876.7$ & $3771,538.3$ & 1393 & 721 & 52 & 1520 & 48.4 & 3 \\
\hline 3 & Station \#3 & $379,814.9$ & $3774,746.4$ & 5380 & 500 & 9 & 2870 & 57.8 & 2 \\
\hline 4 & $\mathrm{~A}_{1}$ & $378,845.2$ & $3772,814.1$ & 4180 & 699 & 17 & 3250 & 47.8 & 1 \\
\hline 5 & $\mathrm{~A}_{2}$ & 379,039 & $3772,515.5$ & 1900 & 701 & 37 & 1233 & 49 & 4 \\
\hline 6 & $\mathrm{~A}_{3}$ & $380,039.6$ & $3772,178.6$ & 5100 & 753 & 15 & 3360 & 55.3 & 2 \\
\hline 7 & $\mathrm{~B}_{1}$ & $384,971.4$ & $3770,472.2$ & 719 & 537 & 75 & 328 & 42.5 & 13 \\
\hline 8 & $\mathrm{~B}_{2}$ & $378,029.07$ & $3771,914.33$ & 1870 & 603 & 32 & 1881 & 49.9 & 3 \\
\hline 9 & $\mathrm{~B}_{3}$ & $387,140.8$ & $3770,803.4$ & 637 & 350 & 55 & 297 & 63.7 & 21 \\
\hline 10 & $\mathrm{~B}_{4}$ & $373,957.6$ & 3771,549 & 935 & 935 & 100 & 52.3 & 52.3 & 100 \\
\hline 11 & $\mathrm{~B}_{5}$ & $377,108.9$ & $3773,397.7$ & 886 & 703 & 79 & 226 & 41.1 & 18 \\
\hline 12 & $\mathrm{C}_{1}$ & $36,707.9$ & $376,483.9$ & 1880 & 1880 & 100 & 325 & 325 & 100 \\
\hline
\end{tabular}

Table $11 \mathrm{CO}$ concentration with contribution of only industries

\begin{tabular}{|c|c|c|c|c|c|c|c|c|c|}
\hline Item & $\begin{array}{l}\text { CO Measure- } \\
\text { ment loca- } \\
\text { tion only for } \\
\text { industries }\end{array}$ & $x$ & $Y$ & $\begin{array}{l}\text { Concen- } \\
\text { tration in } \\
\text { spring } \\
\mu \mathrm{g} / \mathrm{m}^{3}\end{array}$ & $\begin{array}{l}\text { Industries- } \\
\text { caused con- } \\
\text { centration in } \\
\text { spring } \\
\mu \mathrm{g} / \mathrm{m}^{3}\end{array}$ & $\begin{array}{l}\text { Share of indus- } \\
\text { tries from total } \\
\text { concentration } \\
(\%)\end{array}$ & $\begin{array}{l}\text { Concen- } \\
\text { tration in } \\
\text { fall } \\
\mu \mathrm{g} / \mathrm{m}^{3}\end{array}$ & $\begin{array}{l}\text { Industries- } \\
\text { caused concen- } \\
\text { tration in fall } \\
\mu \mathrm{g} / \mathrm{m}^{3}\end{array}$ & $\begin{array}{l}\text { Share of indus- } \\
\text { tries from total } \\
\text { concentration } \\
(\%)\end{array}$ \\
\hline 1 & Station \#1 & $382,726.2$ & $3774,239.4$ & 19,200 & 19,200 & 100 & 18,200 & 18,200 & 100 \\
\hline 2 & Station \#2 & $377,876.7$ & $3771,538.3$ & 46,121 & 42,200 & 91 & 8740 & 7893 & 90 \\
\hline 3 & Station \#3 & $379,814.9$ & $3774,746.4$ & 39,200 & 18,446 & 47 & 18,719 & 9264 & 49 \\
\hline 4 & $\mathrm{~A}_{1}$ & $378,845.2$ & $3772,814.1$ & 49,646 & 39,300 & 79 & 31,300 & 17,429 & 56 \\
\hline 5 & $\mathrm{~A}_{2}$ & 379,039 & $3772,515.5$ & 57,032 & 48,727 & 85 & 26,500 & 22,200 & 84 \\
\hline 6 & $\mathrm{~A}_{3}$ & $380,039.6$ & $3772,178.6$ & 78,027 & 45,200 & 58 & 49,800 & 18,300 & 37 \\
\hline 7 & $\mathrm{~B}_{1}$ & $384,971.4$ & $3770,472.2$ & 23,137 & 23,137 & 100 & 31,300 & 31,300 & 100 \\
\hline 8 & $\mathrm{~B}_{2}$ & $378,029.07$ & $3771,914.3$ & 47,100 & 35,343 & 75 & 17,400 & 11,525 & 66 \\
\hline 9 & $\mathrm{~B}_{3}$ & $387,140.8$ & $3770,803.4$ & 18,448 & 18,200 & 99 & 22,822 & 22,800 & 100 \\
\hline 10 & $\mathrm{~B}_{4}$ & $373,957.6$ & 3771,549 & 4640 & 4521 & 97 & 3970 & 3882 & 98 \\
\hline 11 & $\mathrm{~B}_{5}$ & $377,108.9$ & $3773,397.7$ & 36,849 & 34,800 & 94 & 28,414 & 14,400 & 51 \\
\hline 12 & $\mathrm{C}_{1}$ & $36,707.9$ & $376,483.9$ & 1971 & 1970 & 100 & 2083 & 2080 & 100 \\
\hline
\end{tabular}

$12,913 \mu \mathrm{g} / \mathrm{m}^{3}, 1.29$ times of allowable limit. Though improvement is undeniable, again, air suffers from pollution. in summer, however, only three measuring points experience a higher value of concentration. Totally, on average, the concentration was $7461 \mu \mathrm{g} / \mathrm{m}^{3}$ which lower than the standard limit which is favorable.

For the case of $\mathrm{SO}_{2}$ modeling was only performed with more critical seasons namely spring and summer. Table 15 presents different concentration for 12 measuring points within the city. Considering the results,
IRALCO is the only responsible with $100 \%$ share of the pollution. The impact of this industry is striking as, on average, for spring and summer the concentration of $\mathrm{SO}_{2}$ was 37 and 13.5 times higher than the standard level respectively. Moreover, cutting IRALCO pollution volume to half no promising result is imaginable as, in this state for spring and summer, the average concentration becomes 21 and 6.7 times higher-than-standard limit, respectively. 
Table 12 Concentration of $\mathrm{SO}_{2}$ when only the contribution of industries is considered

\begin{tabular}{|c|c|c|c|c|c|c|c|c|c|}
\hline Item & $\begin{array}{l}\mathrm{SO}_{2} \text { Measure- } \\
\text { ment loca- } \\
\text { tion only for } \\
\text { industries }\end{array}$ & $x$ & $Y$ & $\begin{array}{l}\text { Concen- } \\
\text { tration in } \\
\text { spring } \\
\mu \mathrm{g} / \mathrm{m}^{3}\end{array}$ & $\begin{array}{l}\text { Industries- } \\
\text { caused con- } \\
\text { centration in } \\
\text { spring } \\
\mu \mathrm{g} / \mathrm{m}^{3}\end{array}$ & $\begin{array}{l}\text { Share of indus- } \\
\text { tries from total } \\
\text { concentration } \\
(\%)\end{array}$ & $\begin{array}{l}\text { Concen- } \\
\text { tration in } \\
\text { fall } \\
\mu \mathrm{g} / \mathrm{m}^{3}\end{array}$ & $\begin{array}{l}\text { Industries- } \\
\text { caused concen- } \\
\text { tration in fall } \\
\mu \mathrm{g} / \mathrm{m}^{3}\end{array}$ & $\begin{array}{l}\text { Share of indus- } \\
\text { tries from total } \\
\text { concentration } \\
(\%)\end{array}$ \\
\hline 1 & Station \#1 & 382726.2 & $3774,239.4$ & 3580 & 3580 & 100 & 2092 & 2092 & 100 \\
\hline 2 & Station \#2 & $377,876.7$ & $3771,538.3$ & 11,100 & 11,100 & 100 & 5280 & 5280 & 100 \\
\hline 3 & Station \#3 & $379,814.9$ & $3774,746.4$ & 3310 & 3310 & 100 & 1910 & 1910 & 100 \\
\hline 4 & $\mathrm{~A}_{1}$ & $378,845.2$ & $3772,814.1$ & 10,700 & 10,700 & 100 & 4020 & 4020 & 100 \\
\hline 5 & $\mathrm{~A}_{2}$ & 379,039 & $3772,515.5$ & 11,100 & 11,100 & 100 & 5280 & 5280 & 100 \\
\hline 6 & $\mathrm{~A}_{3}$ & $380,039.6$ & $3772,178.6$ & 7472 & 7472 & 100 & 3350 & 3350 & 100 \\
\hline 7 & $\mathrm{~B}_{1}$ & $384,971.4$ & $3770,472.2$ & 3910 & 3910 & 100 & 3104 & 3104 & 100 \\
\hline 8 & $\mathrm{~B}_{2}$ & $378,029.07$ & $3771,914.3$ & 10,600 & 10,600 & 100 & 2621 & 2621 & 100 \\
\hline 9 & $\mathrm{~B}_{3}$ & $387,140.8$ & $3770,803.4$ & 4640 & 4640 & 100 & 3064 & 3064 & 100 \\
\hline 10 & $\mathrm{~B}_{4}$ & $373,957.6$ & 3771,549 & 1170 & 1170 & 100 & 804 & 804 & 100 \\
\hline 11 & $\mathrm{~B}_{5}$ & $377,108.9$ & $3773,397.7$ & 15,500 & 15,500 & 100 & 3300 & 3300 & 100 \\
\hline 12 & $\mathrm{C}_{1}$ & $36,707.9$ & $376,483.9$ & 2090 & 2090 & 100 & 421 & 421 & 100 \\
\hline
\end{tabular}

\section{Conclusion}

Considering the concentration of $\mathrm{NO}_{x}$ there are three contributing factors for air pollution of Arak, namely cars, IRALCO, and Arak Petrochemical company (ARPC). For the first factor, different amendments like developing public transportation and supportive policies for more usage of clean vehicles like electricity motorbikes, scooters, or bicycles. Considering traffic restriction policies especially for city center and widening current roads or building new highways is also beneficial to reduce traffic jams. For the second factor, the immediate measure would be to transform the physical location of the company to the distant place corresponding to the town. Pollution came out of this company in springs, falls, and winters, is devastating to the health of citizens, and though costly and ineffective, it should be followed immediately. For the third factor, it was proved that the pollution emitted by this company can reach the city especially in springs and winters. Therefore, it can be advised to reduce the capacity of production during this time. Using advanced filtration is another alternative.

Considering the concentration of $\mathrm{CO}$, there are two major contributing factors for air pollution of Arak, namely cars and IRALCO.

For the first factor modification of roads and traffic intersections, the development of clean public transportation, CNG-combustion public transportation vehicle, improving management of passenger terminal, making traffic control systems smart, ruling out worn-out vehicle from the transportation loops specifically buses, minibuses, and taxies, conducting urban traffic policies like specifying restrict traffic zones, facilitation electronic state to reduce inner city travels, and establishing cars technical diagnosis centers can be consulted.

For the second-factor relocation of the factory, renovation of the old production lines including reduction and anodizing lines can be mentioned.

Considering the concentration of $\mathrm{SO}_{2}$, there are two major contributing factors that can be considered for air pollution of Arak, namely Refinery and IRALCO. For the first time, installation of new filtration systems or reduction of the production capacity can be advised. For the second factor, similar aforementioned can be considered.

The air pollution is important problem in many cities. In all reduction strategies, it is expected that the process optimized, so the production pollutant is reduced. In some cases, as Arak city, the results show that the pollutant is few times of standard and any modification strategies could not yield to appropriate level of pollutants. Thus, the only solution is restrictions, for example, limitation of factories production, transfer of factories far from the city, and applying traffic plan. Finally, in this research, it is tried to prove that the pollution could not be decreased unless the restriction will be applied, so the author hope it will be found by the reader.

It should be noticed that authors are currently investigating other pollutants like PM2.5, PM10, and HF, and Benzene derivatives to introduce a comprehensive pollution reduction plan for air pollution of Arak. Moreover, presented study should be repeated for 5-year intervals to more accurately evaluate pollution reduction statistics. 

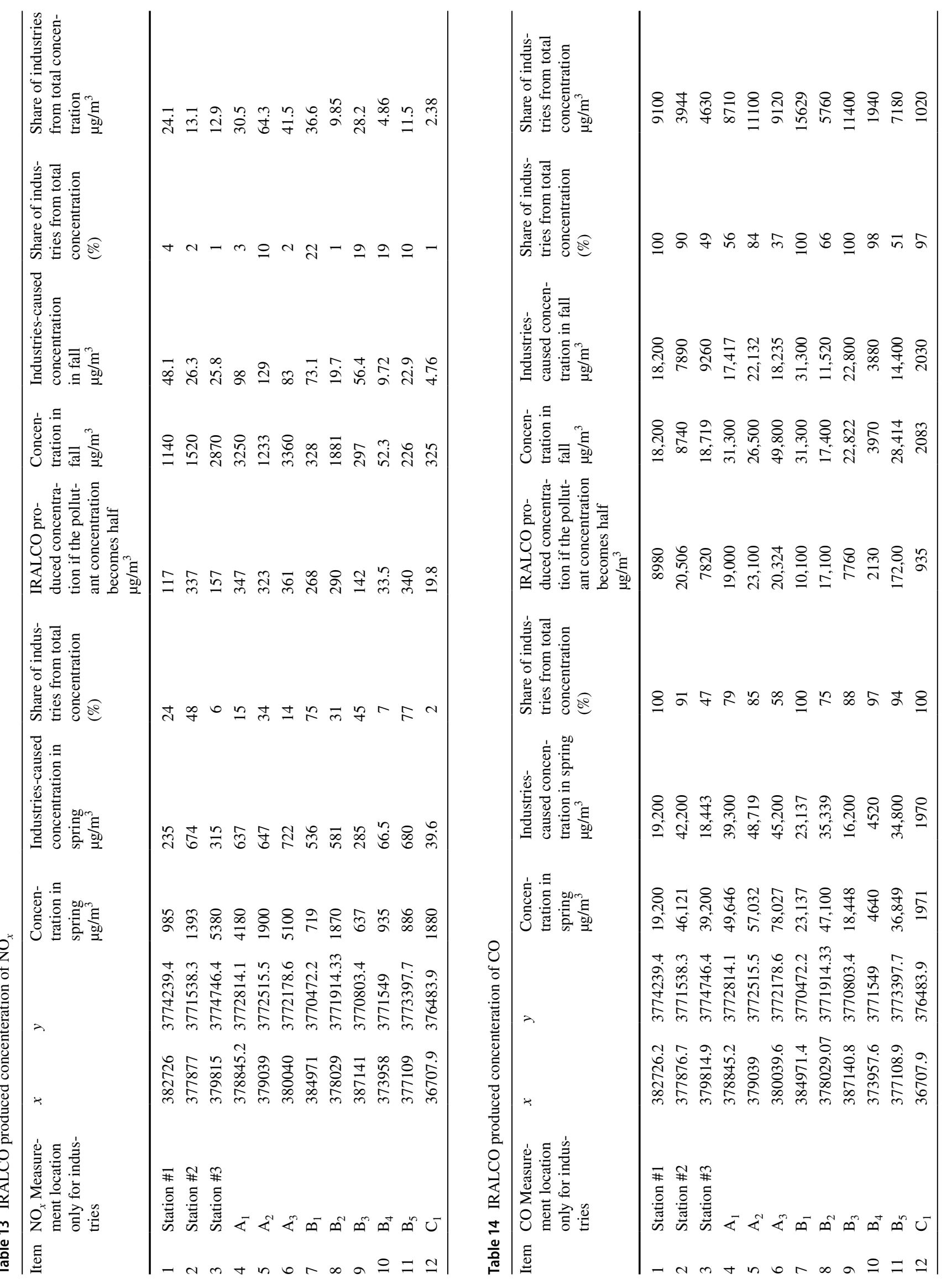


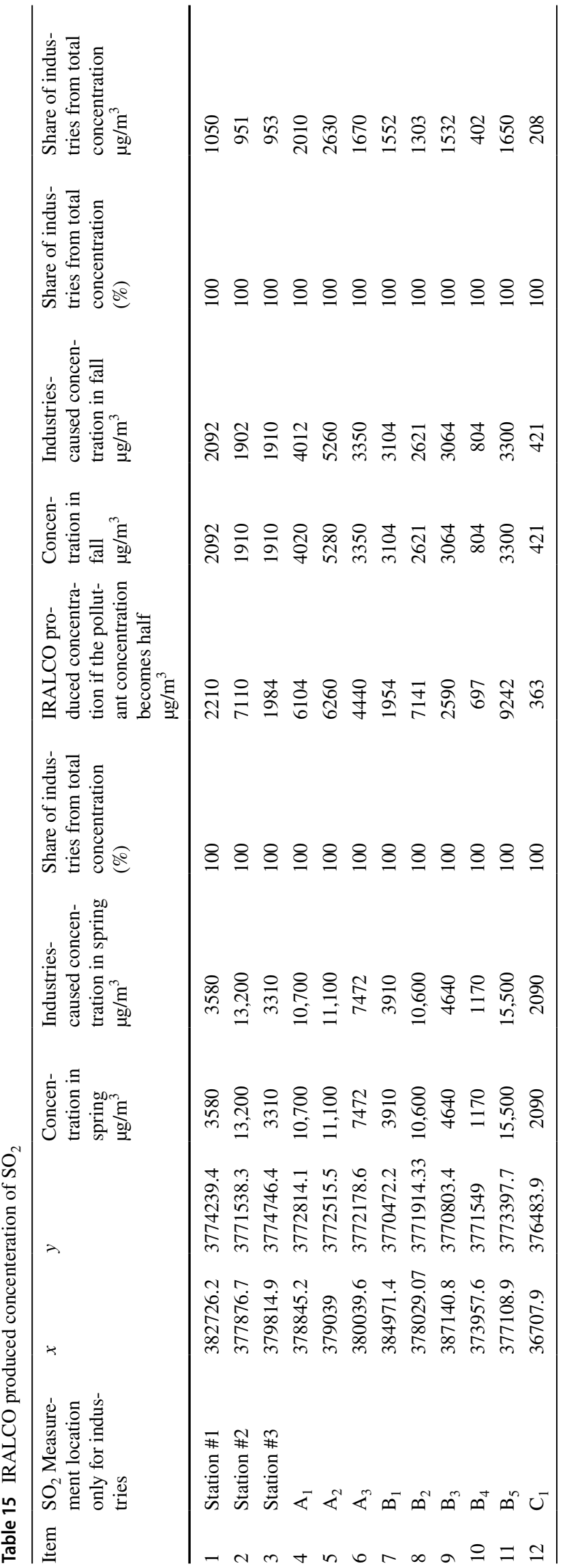

\section{References}

1. Air pollution. (2019) Retrieved 16 March 2020, from https:// www.who.int/health-topics/air-pollution\#tab=tab_1

2. Peel, J.L., Haeuber, R., Garcia, V., Russell, A.G., Neas, L.: Impact of nitrogen and climate change interactions on ambient air pollution and human health. Biogeochemistry 114(1-3), 121-134 (2013)

3. Kampa, M., Castanas, E.: Human health effects of air pollution. Environ. Pollut. 151(2), 362-367 (2008)

4. Pandey, J.S., Kumar, R., Devotta, S.: Health risks of $\mathrm{NO}_{2}$, SPM and $\mathrm{SO}_{2}$ in Delhi (India). Atmos. Environ. 39(36), 6868-6874 (2005)

5. Taksibi, F., Khajehpour, H., Saboohi, Y.: On the environmental effectiveness analysis of energy policies: a case study of air pollution in the megacity of Tehran. Sci. Total Environ. 705, 135824 (2020)

6. Pinto, J.A., Kumar, P., Alonso, M.F., Andreão, W.L., Pedruzzi, R., dos Santos, F.S., et al.: Traffic data in air quality modeling: a review of key variables, improvements in results, open problems and challenges in current research. Atmos. Pollut. Res. (2019)

7. Tong, R., Liu, J., Wang, W., Fang, Y.: Health effects of PM2. 5 emissions from on-road vehicles during weekdays and weekends in Beijing, China. Atmos. Environ. 117258 (2020)

8. Tayarani, M., Rowangould, G.: Estimating exposure to fine particulate matter emissions from vehicle traffic: exposure misclassification and daily activity patterns in a large, sprawling region. Environ. Res. 182, 108999 (2020)

9. Torrente-Velásquez, J.M., Giampietro, M., Ripa, M., Chifari, R.: Landfill reactions to society actions: the case of local and global air pollutants of Cerro Patacón in Panama. Sci. Total Environ. 706, 135988 (2020)

10. Ghanbari Fard, R., Safavi, A., Setoodeh, P.: The traffic flow effect modeling on the air pollution of Shiraz city. J. Environ. Sci. Res. Inst. 15(1), 157-174 (2017)

11. Baker, J., Battye, W.H., Robarge, W., Arya, S.P., Aneja, V.P.: Modeling and measurements of ammonia from poultry operations: their emissions, transport, and deposition in the Chesapeake Bay. Sci. Total Environ. 706, 135290 (2020)

12. Atabi, F., Jafarigol, F., Momeni, M., Salimian, M., Bahmannia, G.: Dispersion modeling of CO with AERMOD in South Pars fourth gas refinery. J. Environ. Health Eng. 1(4), 281-292 (2014)

13. Moemeni, I., Danehkar, A., Karimi, S.: Dispersion modelling of $\mathrm{SO}_{2}$ pollution emitted from Ramin Ahwaz power plant using AERMOD model. J. Iran Soc. Environ. 9(3), 3-8 (2011)

14. Nourpour, A., Shahabi, N.: Dispersion modeling of air pollutants from the ilam cement factory stack. J. Civ. Environ. Eng. 1(44), 107-116 (2014)

15. Ramavandi, B., Ahmadi Moghaddam, M., Shah Heidar, N., Bighami, M.: Estimation of volatile organic compounds emissions from the fuel storage tanks using TANKS model and its distribution modeling by AERMOD model. J. Ferdosi Mashhad Univ. 23(2), 253-261 (2016)

16. Mosavi, M., Bahrpeyma, S., Rezazadeh, R.: Investigation of air pollution caused by three power plants in Mashhad using the Gaussian model. J. Environ. Health Eng. (2003)

17. Sharma, S., Zhang, M., Gao, J., Zhang, H., Kota, S.H.: Effect of restricted emissions during COVID-19 on air quality in India. Sci. Total Environ. 728, 138878 (2020)

18. Mentese, S., Mirici, N.A., Elbir, T., Tuygun, G.T., Bakar, C., Otkun, M.T., Oymak, S.: A comprehensive assessment of ambient air quality in Çanakkale city: emission inventory, air quality monitoring, source apportionment, and respiratory health indicators. Atmos. Pollut. Res. 11, 2282-2296 (2020)

19. Chen, S., Broday, D.M.: Re-framing the Gaussian dispersion model as a nonlinear regression scheme for retrospective air 
quality assessment at a high spatial and temporal resolution. Environ. Model. Softw. 125, 104620 (2020)

20. Damuchali, A.M., Guo, H.: Developing an odour emission factor for an oil refinery plant using reverse dispersion modeling. Atmos. Environ. 222, 117167 (2020)

21. de Ferreyro Monticelli, D., Santos, J.M., Dourado, H.O., Moreira, D.M., Reis, N.C., Jr.: Assessing particle dry deposition in an urban environment by using dispersion models. Atmos. Pollut. Res. 11(1), 1-10 (2020)

22. Dunkerley, F., Spanton, A., Hall, D., Bennett, M., \& Griffiths, R.: An intercomparison of the AERMOD, ADMS and ISC dispersion models for regulatory applications: dispersion over terrain. Paper presented at the 7th International Conference on Harmonisation within Atmospheric Dispersion Modelling for Regulatory Purposes. HARMO7. 28-31 May, Belgirate, Italy (2001)

23. Gómez-Losada, Á., Santos, F.M., Gibert, K., Pires, J.C.: A data science approach for spatiotemporal modelling of low and resident air pollution in Madrid (Spain): implications for epidemiological studies. Comput. Environ. Urban Syst. 75, 1-11 (2019)

24. Lin, X., Li, M., Chen, Z., Chen, T., Li, X., Wang, C., et al.: Longterm monitoring of PCDD/Fs in soils in the vicinity of a hazardous waste incinerator in China: temporal variations and environmental impacts. Sci. Total Environ. 713, 136717 (2020)
25. Mbiaké, R., Mfoumou, E., Wakata, A.B., Ndjeuna, E., Djamen, J.K., Leduc, R., Bobda, C.: Atmospheric dispersion modeling of the emissions from the logbaba thermal power plant, DoualaCameroon. Open J. Air Pollut. 6(4), 117-134 (2017)

26. Valencia, V. H., Hertel, O., Ketzel, M., Levin, G.: Modeling urban background air pollution in Quito, Ecuador. Atmos. Pollut. Res. (2019)

27. Zhou, W.-Y., Xie, Y.-X., Zhang, J., Deng, S.-H., Shen, F., Xiao, $\mathrm{H}$., et al.: Estimating the remaining atmospheric environmental capacity using a single-box model in a high pollution risk suburb of Chengdu, China. J. Environ. Manag. 258, 110052 (2020)

28. Bady, M.: Fundamentals of direct inverse CFD modeling to detect air pollution sources in urban areas. (2013)

29. Arak, Iran. Retrieved 20 April 2020, from https://en.wikipedia. org/wiki/Arak,_Iran, (2020)

30. Anonymous: AERMOD View Help, Lakes Environmental Software, AERMODVW760 (2012)

31. Guttikunda, S.: Air Quality Index (AQI): Methodology and applications for public awareness in cities. Available from www.simair.org. (2010)

Publisher's Note Springer Nature remains neutral with regard to jurisdictional claims in published maps and institutional affiliations. 